University of Wollongong

Research Online

Faculty of Science, Medicine and Health -

Papers: part A

Faculty of Science, Medicine and Health

$1-1-2014$

Depositional history and archaeology of the central Lake Mungo lunette, Willandra Lakes, southeast Australia

Kathryn E. Fitzsimmons

Max Planck Institute, Germany

Nicola Stern

La Trobe University

Colin V. Murray-Wallace

University of Wollongong, cwallace@uow.edu.au

Follow this and additional works at: https://ro.uow.edu.au/smhpapers

Part of the Medicine and Health Sciences Commons, and the Social and Behavioral Sciences

Commons

Recommended Citation

Fitzsimmons, Kathryn E.; Stern, Nicola; and Murray-Wallace, Colin V., "Depositional history and archaeology of the central Lake Mungo lunette, Willandra Lakes, southeast Australia" (2014). Faculty of Science, Medicine and Health - Papers: part A. 1111.

https://ro.uow.edu.au/smhpapers/1111

Research Online is the open access institutional repository for the University of Wollongong. For further information contact the UOW Library: research-pubs@uow.edu.au 


\title{
Depositional history and archaeology of the central Lake Mungo lunette, Willandra Lakes, southeast Australia
}

\begin{abstract}
Lake Mungo, presently a dry lake in the semi-arid zone of southeastern Australia, preserves a unique record of human settlement and past environmental change within the transverse lunette that built up on its downwind margin. The lunette is $>30 \mathrm{~km}$ long and the variable morphology along its length suggests spatial variability in deposition over time. Consequently this presents differential potential for the preservation of past activity traces of different ages along the lunette. Earlier work at Lake Mungo focused primarily on the southern section of the lunette, where two ritual burials of considerable antiquity were found. Here we describe the depositional history of the central section of the Lake Mungo lunette, together with the first single grain optically stimulated luminescence (OSL) chronology of the full stratigraphic sequence and of three hearths. We thereby lay the foundation for systematic investigation of the distribution of archaeological traces through the sedimentary record.

The older depositional units (Lower and Upper Mungo) were deposited ca. 50-40 ka and $\sim 34 \mathrm{ka}$ respectively, and are substantially thinner in the central section of the lunette compared with the south. By contrast, the overlying unit of interbedded sands and clayey sands (Arumpo-Zanci units), deposited ca. 25-14 ka, is markedly thicker and dominates the stratigraphic sequence in the central portion of the lunette. Although the sequence broadly reflects previous models of the lunette's depositional history and changing hydrological conditions, our results indicate spatially variable deposition of sediments, possibly as a result of changes in prevailing wind regimes. Archaeological traces are exposed in all stratigraphic units deposited after ca. $50 \mathrm{ka}$, including sediments deposited after the final lake drying ca. $15 \mathrm{ka}$, indicating human occupation of the area under a range of palaeoenvironmental conditions. Dating and stratigraphical examination of individual hearth features demonstrates that even within individual stratigraphic units, human occupation persisted under variable conditions. Mid-Holocene occupation of the area following the final lake retreat took place during a period of relatively humid climate.
\end{abstract}

\section{Keywords}

lunette, willandra, lakes, southeast, australia, depositional, history, archaeology, central, lake, mungo

\section{Disciplines}

Medicine and Health Sciences | Social and Behavioral Sciences

\section{Publication Details}

Fitzsimmons, K. E., Stern, N. \& Murray-Wallace, C. V. (2014). Depositional history and archaeology of the central Lake Mungo lunette, Willandra Lakes, southeast Australia. Journal of Archaeological Science, 41 349-364. 


\section{Elsevier Editorial System(tm) for Journal of Archaeological Science}

Manuscript Draft

\section{Manuscript Number: JASC13-22R1}

Title: Depositional history and archaeology of the central Lake Mungo lunette, Willandra Lakes, southeast Australia

Article Type: Full Length Article

Keywords: Lake Mungo; Willandra Lakes; optically stimulated luminescence (OSL) dating; Pleistocene archaeology; Holocene archaeology; Australia

Corresponding Author: Dr. Kathryn Fitzsimmons, PhD

Corresponding Author's Institution: Max Planck Institute for Evolutionary Anthropology

First Author: Kathryn E Fitzsimmons, PhD

Order of Authors: Kathryn E Fitzsimmons, PhD; Nicola Stern, PhD; Colin V Murray-Wallace, PhD

Abstract: Lake Mungo, presently a dry lake in the semi-arid zone of southeastern Australia, preserves a unique record of human settlement and past environmental change within the transverse lunette that built up on its downwind margin. The lunette is $>30 \mathrm{~km}$ long and the variable morphology along its length suggests spatial variability in deposition along over time. Consequently this presents differential potential for the preservation of past activity traces of different ages along the lunette. Earlier work at Lake Mungo focused primarily on the southern section of the lunette, where two ritual burials of considerable antiquity were found. Here we describe the depositional history of the central section of the Lake Mungo lunette, together with the first single grain optically stimulated luminescence (OSL) chronology of the full stratigraphic sequence and of three hearths. We thereby lay the foundation for systematic investigation of the distribution of archaeological traces through the sedimentary record. The older depositional units (Lower and Upper Mungo) were deposited ca. 50-40 ka and 34 ka respectively, and are substantially thinner in the central section of the lunette compared with the south. By contrast, the overlying unit of interbedded sands and clayey sands (Arumpo-Zanci units), deposited ca. 25-14 ka, is markedly thicker and dominates the stratigraphic sequence in the central portion of the lunette. Although the sequence broadly reflects previous models of the lunette's depositional history and changing hydrological conditions, our results indicate spatially variable deposition of sediments, possibly as a result of changes in prevailing wind regimes. Archaeological traces are exposed in all stratigraphic units deposited after ca. $50 \mathrm{ka}$, including sediments deposited after the final lake drying ca. $15 \mathrm{ka}$, indicating human occupation of the area under a range of palaeoenvironmental conditions. Dating and stratigraphical examination of individual hearth features demonstrates that even within individual stratigraphic units, human occupation persisted under variable conditions. Mid-Holocene occupation of the area following the final lake retreat took place during a period of relatively humid climate. 


\section{HIGHLIGHTS}

- Spatial variation in stratigraphic thickness along lunette - implications for past wind regimes

- First single grain OSL chronology of complete lunette sequence

- Human occupation under range of environmental conditions

- Variable density of archaeological traces may reflect changes in settlement patterns

Variable density of archaeological traces may reflect changes in settlement patterns 
2

3

\section{Depositional history and archaeology of the central Lake Mungo lunette, Willandra Lakes,} southeast Australia

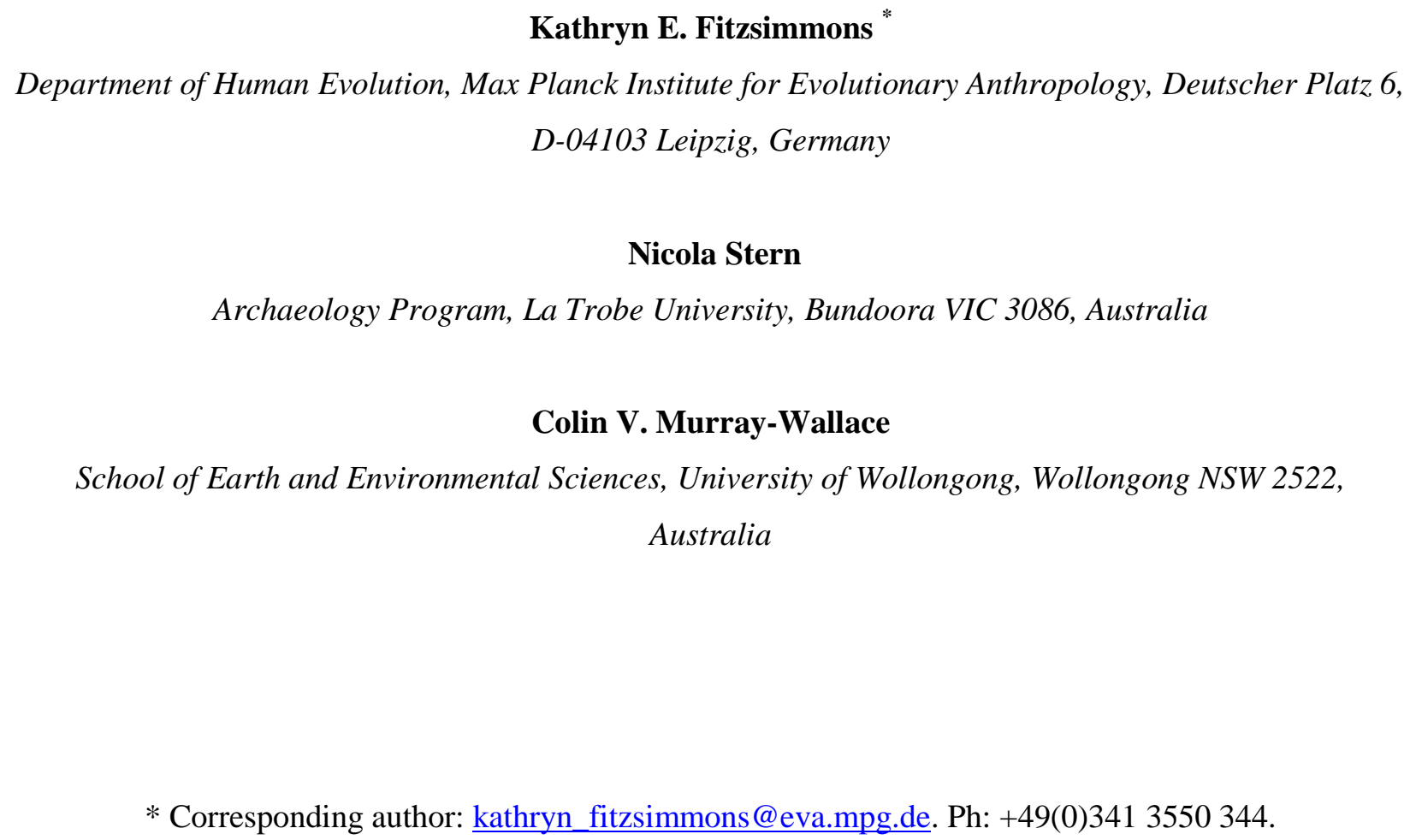




\section{ABSTRACT}

20 Lake Mungo, presently a dry lake in the semi-arid zone of southeastern Australia, preserves a unique

21 record of human settlement and past environmental change within the transverse lunette that built up on

22 its downwind margin. The lunette is $>30 \mathrm{~km}$ long and the variable morphology along its length suggests

23 spatial variability in deposition along over time. Consequently this presents differential potential for the

24 preservation of past activity traces of different ages along the lunette. Earlier work at Lake Mungo

25 focused primarily on the southern section of the lunette, where two ritual burials of considerable antiquity

26 were found. Here we describe the depositional history of the central section of the Lake Mungo lunette,

27 together with the first single grain optically stimulated luminescence (OSL) chronology of the full

28 stratigraphic sequence and of three hearths. We thereby lay the foundation for systematic investigation of

29 the distribution of archaeological traces through the sedimentary record.

30 The older depositional units (Lower and Upper Mungo) were deposited ca. 50-40 ka and 34 ka 31 respectively, and are substantially thinner in the central section of the lunette compared with the south. By 32 contrast, the overlying unit of interbedded sands and clayey sands (Arumpo-Zanci units), deposited ca. 33 25-14 ka, is markedly thicker and dominates the stratigraphic sequence in the central portion of the 34 lunette. Although the sequence broadly reflects previous models of the lunette's depositional history and 35 changing hydrological conditions, our results indicate spatially variable deposition of sediments, possibly 36 as a result of changes in prevailing wind regimes. Archaeological traces are exposed in all stratigraphic 37 units deposited after ca. $50 \mathrm{ka}$, including sediments deposited after the final lake drying ca. $15 \mathrm{ka}$, 38 indicating human occupation of the area under a range of palaeoenvironmental conditions. Dating and 39 stratigraphical examination of individual hearth features demonstrates that even within individual 40 stratigraphic units, human occupation persisted under variable conditions. Mid-Holocene occupation of 41 the area following the final lake retreat took place during a period of relatively humid climate. 


\section{HIGHLIGHTS}

44 - Spatial variations in stratigraphic thickness along lunette-implications for past wind regimes

45 - First single grain OSL chronology of complete lunette sequence

46 - Human occupation under range of environmental conditions

47 - Variable density of archaeological traces may reflect changes in settlement patterns

\section{KEYWORDS}

49 Lake Mungo, Willandra Lakes, optically stimulated luminescence (OSL) dating, Pleistocene archaeology, 


\section{INTRODUCTION}

52 The Willandra Lakes, a system of presently dry lakes within the semi-arid zone of southeastern Australia, 53 preserve a record of both archaeological and palaeoenvironmental significance. The best known of these 54 lakes, Lake Mungo, is renowned for the preservation, within the transverse lunette dune on its downwind 55 margins, of some of the earliest known archaeological traces on the Australian continent, including the world's oldest known cremation and ritual burial (Bowler et al. 1970; Bowler and Thorne 1976; Bowler et al. 2003). The Willandra Lakes are a relict overflow system, once fed by the Willandra Creek, a distributary of the Lachlan River which has its headwaters in the southeastern Australian highlands. The lakes experienced episodic sediment deposition onto their lunettes throughout the last full glacial cycle. Lunette sedimentation therefore reflects changes in lake palaeohydrology over this time period (Bowler 1998). The Willandra Lake lunettes, including that of Lake Mungo, therefore provide an important opportunity to document the interplay between human and environmental history over long timescales (Mulvaney and Bowler 1981; Stern et al. 2013), in a climatically sensitive region which provides relatively few semi-continuous sedimentary records (Fitzsimmons et al. in press).

The Lake Mungo lunette is the best-studied landform within the Willandra Lakes system, both in terms of its depositional history (Bowler 1971, 1998; Bowler et al. 2003, 2012) and the past activity traces it contains (e.g. Bowler et al. 1970; Allen 1998; Gillespie 1998; Shawcross 1998; Hiscock and Allen 2000). However, a surprising paucity of systematic archaeological research over the past 40 years means that the potential for integrating the archaeological and geological records has not yet been realized (c.f. Bowler 1998; Bowler et al. 2003). As a result, current understanding of human-environment interactions is extremely limited, despite the considerable potential for exploring these relationships at varying scales of analysis in this kind of landscape (Fanning and Holdaway 2002; Fanning et al. 2007; Stern 2008). Furthermore, geochronological studies were undertaken with a bias towards the southern end of the lunette where the oldest burials were found, and focused on establishing their antiquity (Bowler et al. 1972; Adams and Mortlock 1974; Mortlock 1974; Chappell et al. 1996; Oyston 1996; Bowler and Price 1998; Gillespie 1998; Thorne et al. 1999; Bowler et al. 2003; Olley et al. 2006).

The stratigraphy of the Lake Mungo lunette reflects a sequence of wetting and drying cycles from significantly before the last interglacial (Marine Isotope Substage (MIS) 5e) to the present (Bowler and Price 1998). Lake Mungo was full when humans first settled the area ca. $45 \mathrm{ka}$. This was followed by multiple oscillations in lake level. The final lake retreat occurred in association with the cessation of flow in Willandra Creek, the major inflow channel, shortly after the Last Glacial Maximum (LGM; Bowler 
84 1998). Both palaeoenvironmental and archaeological studies predominantly focused on the late 85 Pleistocene until final lake desiccation, despite the fact that humans continued to occupy the landscape 86 after this time (Johnston and Clark 1998; Stern et al. 2013). The nature of environmental change after ca. $8717 \mathrm{ka}$, and human responses to changes in local conditions after this time, is particularly poorly 88 understood.

90 This paper focuses on the relatively understudied central portion of the Lake Mungo lunette. We examine 91 the depositional history within a geochronological framework for this section, and integrate this 92 information with the distribution of archaeological traces and three individual hearth features in this area. 93 In this study we reassess the existing stratigraphical model for the Lake Mungo lunette based on our 94 optically stimulated luminescence (OSL) dating chronology, detailed stratigraphical mapping and 95 transect, and speculate on the spatial variability of lunette formation through time and its implications for 96 the archaeological record. Finally, this study provides additional palaeoenvironmental context for 97 understanding human adaptation to changing conditions in this region, extending beyond the final lake 98 retreat and into the Holocene.

\section{REGIONAL SETTING}

101 Lake Mungo is a presently dry overflow lake within the Willandra Lakes system, located in semi-arid 102 southwest New South Wales, Australia (Figure 1). The Willandra Lakes lie within a landscape 103 dominated by the aeolian and fluvial landforms of the southwest Murray-Darling Basin (MDB), the 104 largest catchment in southeastern Australia. These interdigitating deposits record a long succession of 105 palaeohydrological and palaeoenvironmental change, reflecting both regional and local climatic 106 influences (Bowler 1971; Bowler 1976; Bowler and Magee 1978; Bowler 1998; Bowler et al. 2006).

Insert Figure 1 here

The Willandra Lakes comprise a series of five major (and numerous smaller) dry lakes, fed almost entirely by the Willandra Creek, a presently inactive channel of the palaeo-Lachlan River (Kemp and 
17 the Willandra Lakes system more closely reflected runoff from the southeastern Australian highlands rather than local conditions. The levels of individual lakes were influenced by their position within the 119 overflow system.

The palaeohydrology of each lake within the Willandra system is recorded in its lunette, the transverse dune which lies immediately downwind on the eastern lake margin (Bowler 1983) (Figure 1). Lake full conditions combined with prevailing south-westerly winds resulted in the transport of clean sands to the eastern margins of each lake, forming transverse crescentic dunes. In contrast, oscillating lake levels or drying conditions facilitated the formation of sand-sized aggregates of clay ("clay pellets"), which in 126 addition to sand were blown onto the lunettes (Hills 1940; Bowler 1973; Bowler 1983). The Willandra Lake lunettes each preserve stratigraphic packages comprising beach gravels and sandy sediments reflecting perennial lake phases, alternating with layers containing clay pellets reflecting falling lake levels and increased salinity. Periods of relative landscape stability, associated with regional drying or reduced sediment supply from the lake, facilitated pedogenesis within the lunette sediments. Paleosols within the lunettes in this semi-arid environment are characterised by clay illuviation and carbonate precipitation and cementation (Bowler and Magee 1978; Bowler 1998; Young and Young 2002).

Lake Mungo lies within the central portion of the Willandra Lakes system, and filled by overflow from the adjacent Lake Leaghur situated immediately north of Lake Mungo (Figure 1). The palaeohydrology of Lake Mungo, as with all of the Willandra Lakes, was ultimately dependent on inflow from the Willandra Creek, and this is reflected in its lunette stratigraphy. However, because Lake Mungo filled via overflow from Lake Leaghur and had no outflow, it was particularly sensitive to hydrologic changes. 139 Following cessation of flow within the Willandra Creek, reactivation and redeposition of lunette

\section{3. MATERIAL AND METHODS}

\section{$143 \quad 3.1$ Archaeological and stratigraphical survey}

144 Erosion of the Lake Mungo lunette has exposed its stratigraphic units and the archaeological traces 145 incorporated into them, enabling the integration of these two lines of evidence in order to reconstruct human-environmental interactions in the Willandra Lakes. We recorded, over three-dimensional space, 147 the distribution of archaeological traces and the stratigraphical units within which the archaeology was 148 found. This study focuses on a ca. $400 \mathrm{~m}$ wide swath of the central portion of the lunette. The southern 
boundary of the study area lies approximately $200 \mathrm{~m}$ north of the boardwalk at the "Walls of China" tourist site (WOCT) (Figure 2a), originally described by Bowler (1998).

\section{Insert Figure 2 here}

The locations of cultural features were recorded in three-dimensional space using a total station or differential GPS (dGPS) and tied into the Geodetic Datum of Australia. Only archaeological traces with unambiguous stratigraphic provenance were recorded (Stern et al. 2013). Lag and transported assemblages strewn across the eroding surfaces of the lunette were ignored. The Lake Mungo lunette is a dynamic landform and ongoing erosion, even over the several seasons during which the archaeological foot surveys were undertaken, continually exhumes both sediments and archaeological traces. Consequently the record presented in this study represents a snapshot of traces exposed during the period of survey.

Varied activity traces retaining precise stratigraphic provenance are exposed on the surface of the Lake Mungo lunette. Most of these are different types of heat-retainer and non-heat-retainer hearths, many of which are associated with food remains and/or chipped stone artefacts. Heat-retainer hearths primarily comprise non-organic blocks used to retain heat, and are common in environments with a scarcity of organic fuel. Typical materials used in the Willandra Lakes region include pieces of termite mound, calcium carbonate and silcrete nodules, and baked clay. Non-heat-retainer hearths occur in this region as discrete patches of baked sediment or ash. Traces of past activity also include clusters of chipped stone tools and the debris from their manufacture and/or re-working, and clusters of burned animal bone or eggshell. Less common but nevertheless present are small clusters of freshwater bivalves, unworked cobbles, large cores, ground stone tools, shell tools, unworked silcrete cobbles and ochre pellets (Bowler et al. 1970; Allen 1972; Stern et al. 2013).

Lithostratigraphic mapping was completed over three field seasons and involved identification of the stratigraphic units, and characterization of the nature of the stratigraphic boundaries of the principal formations by ground truthing in the field. This was then plotted onto georectified digital air photos as a base map, combined with a hand-held GPS to confirm location. One advantage of the poorly vegetated Lake Mungo lunette is that individual trees, gullies and residuals can be easily identified on the air photos, thus ensuring the accuracy of the ground-truthed mapping. When work began, it was assumed that sedimentary characteristics could be used to trace out distinctive bodies of sediment through the exposures, and that their characteristics and three-dimensional relationships would provide a basis for 
correlation with the stratigraphic units defined previously by Bowler (1998). However, our observations show that this assumption cannot always be applied, for two reasons. First, net accumulation of sediment varied along the length of the lunette, and some stratigraphic units are thin or absent in some areas. Second, the source of sediment remained fundamentally the same throughout the lunette sequence and the hydrologic and wind conditions influencing deposition recurred over time. Consequently, sediments exhibiting similar characteristics occur in more than one part of the stratigraphic sequence. Thus, geochronological data combined with comprehensive ground-truthing are essential to the task of largescale mapping of strata, a strategy that is examined in this study. Identification and characterization of diagnostic features within stratigraphic context, such as paleosols, relative concentrations of clay pellets, sands and clay bands was undertaken in the field by visual inspection.

In addition, a transect across the lunette was studied and sampled for OSL dating. The transect comprises seven residuals and gully features (Figures S1, S2) which best expose the stratigraphical units present at this section of the lunette. Several substantial residuals preserve multiple depositional units. The stratigraphy was logged in the field, with attention paid to stratigraphical boundaries within residuals, paleosols, and sedimentological variation within units (Figure 2b).

Insert links to Figures S1and S2 here

\subsection{OSL dating}

OSL sampling was undertaken to provide a comprehensive chronostratigraphy for the surveyed area (Table 1). OSL samples were collected from each of the seven exposures identified from the stratigraphical survey (Table S1). Where practical, multiple samples were collected from each (Figure 2). In the field, the pale sands and clayey sands of the uppermost lunette unit (E) could not always easily be distinguished from the underlying pale clayey sands (C) due to discontinuous preservation of paleosols. Therefore, as many samples as possible were collected from these paler sediments, from different sites across the lunette. A total of 12 samples were collected from the stratigraphical transect (Figure 2).

\section{Insert Table 1 here}

Insert link to Table S1here

In addition, three hearth features were identified as suitable for OSL dating by collecting bracketing samples from stratigraphically correlated sediment several metres distant. Two samples were collected for 
each of the three hearths, above and below the hearth levels, therefore providing bracketing ages for these features. Thus, a total of 18 OSL samples were collected for this study.

Sites were sampled for OSL by driving $4 \mathrm{~cm}$ diameter, $10 \mathrm{~cm}$ long stainless steel tubes horizontally into cleaned, vertical surfaces. The sample holes were then widened and deepened to accommodate a portable sodium iodide gamma spectrometer with a three-inch crystal detector. Sediment removed during this process was collected in a sealed plastic bag for moisture content and laboratory measurements of radionuclide concentrations. Gamma spectra were measured within each hole for $1800 \mathrm{~s}$. Paleosols were avoided so that sediments which may have experienced post-depositional mixing were not sampled (Bateman et al. 2003). The one exception to this occurred in the case of sampling the lowermost unit, since only its paleosol is exposed in this portion of the lunette. Paleosols in this region are characterised by carbonate precipitation, and by humic enrichment (Bowler and Magee 1978; Bowler 1998).

In the laboratory, the OSL sample tubes were opened and the sediments processed under low intensity red light. Only the sediment in the central section of the tubes was processed for dating. In-situ moisture content was calculated by weighing the raw and oven-dried weight of material from the ends of the tubes, averaged with the moisture content calculated from the sealed plastic bags containing the surrounding sediment. Samples were treated to isolate pure sand-sized quartz, by digestion in dilute hydrochloric acid $(\mathrm{HCl})$ to remove calcium carbonate and hydrogen peroxide to remove any organic fractions, followed by sieving to isolate the $180-212 \mu \mathrm{m}$ sand size fraction, density separation using lithium heterotungstate solution prepared to $2.68 \mathrm{~g} . \mathrm{cm}^{-3}$, and etching in $40 \%$ solution of hydrofluoric acid for 60 minutes, with a final $\mathrm{HCl}$ rinse and sieving to remove small flakes produced as a result of etching. The resulting clean quartz grains were then prepared as both small aliquots (24 discs) and single grains (600 grains, 6 discs). Aliquots were mounted onto the central $3 \mathrm{~mm}$ of three $10 \mathrm{~mm}$ diameter stainless steel discs using silicone oil, and single grains were loaded by sweeping grains over the 100 individual holes of single grain discs with a small brush.

Equivalent dose $\left(D_{e}\right)$ measurements were undertaken using an automated Ris $\varnothing$ TL-DA-20 reader with a single grain attachment, equipped both with blue light-emitting diodes and with a green laser emitting at $532 \mathrm{~nm}$, for light stimulation of single aliquots and single grains respectively (Bøtter-Jensen et al. 2000). Irradiation was provided by calibrated ${ }^{90} \mathrm{Sr} /{ }^{90} \mathrm{Y}$ beta sources (Bøtter-Jensen et al. 2000). Luminescence signals were detected by EMI 9235QA photomultiplier tubes with coated Hoya U-340 filters (BøtterJensen 1997). The $D_{e}$ was measured using the single-aliquot regenerative-dose (SAR) protocol of Murray 
and Wintle (2000; 2003; Supplementary Section). Preheat and cutheat temperatures of $260{ }^{\circ} \mathrm{C}$ and $220{ }^{\circ} \mathrm{C}$ respectively were determined by the results of a preheat plateau test on sample EVA1002 (Figure 4a).

Since not all grains yield useful OSL signals for dating (Jacobs and Roberts 2007), individual grains were analysed for their suitability using a set of selection criteria based on fundamental characteristics. These criteria were defined as grains which emit an OSL signal greater than three times the background level; produce a dose-response curve which can be fitted to a simple exponential function; result in sensitivitycorrected recycling values within $20 \%$ of unity; and yield thermal transfer values of no greater than $5 \%$. With the exception of sample EVA1006 (which contains a high proportion of saturated grains), the number of accepted grains for each sample exceeded 50, the threshold considered acceptable for analysis of the resulting population for age calculation (Rodnight 2008). The resulting $D_{\mathrm{e}}$ values of the samples generally yielded normal distributions (Figures S3, S4, S5). Consequently, the Central Age Model (CAM) of Galbraith et al. (1999) was used for age calculation in all but three samples (see Section 4.2).

Insert links to Figures S3, S4, S5 here

The gamma component of the dose rates was calculated using in situ gamma spectrometry. The beta component was calculated by analyses of the activities of radioactive elements $\mathrm{K}$, Th and $\mathrm{U}$ using high resolution germanium gamma spectrometry, undertaken at the "Felsenkeller" Laboratory (VKTA) in Dresden, Germany, and converted to dose rates using the factors of Adamiec and Aitken (1998). The moisture content of each sample was incorporated into the dose-rate calculations to account for attenuation (Mejdahl 1979). The cosmic ray component of the dose rate was calculated based on equations published in Prescott and Hutton (1994).

\section{RESULTS}

\subsection{Lunette stratigraphy}

The stratigraphy of the central portion of the Lake Mungo lunette comprises nine distinct units (Table 1). This scheme broadly follows but also enlarges on the framework provided by Bowler (1998), through the addition of several aeolian and alluvial units which reflect sediment redeposition following final lake retreat. Since the newly defined units are both laterally extensive (Figure 3) and reflect local palaeoenvironmental changes, they are considered valid and independent stratigraphical units. We observe spatial variability in the thickness of different units along the length of the lunette, which suggests variability in wind regimes through time plus localised sediment supply. 


\section{Insert Figure 3 here}

The oldest unit (A) consists of a strongly developed paleosol, characterised by carbonate rhizomorph precipitation and induration within a well sorted red, medium to coarse grained sand. The sands of this unit were deposited during permanent lake conditions, while subsequent pedogenesis entirely overprinted it. An extensive lag of carbonate pebbles overlying the Unit A surface indicates a later period of weathering. Formation of a wave-cut shoreline cliff ca. $13 \mathrm{~m}$ above the lake floor reflects a subsequent lake full event. This unit contains no archaeological traces, and corresponds to the Golgol unit of previous studies (Bowler 1998; Bowler and Price 1998; Bowler et al. 2003).

The overlying unit (B) comprises unconsolidated well sorted, medium-grained red beach sands, which grade upwards into pale sands and correspond to a perennial lake phase. It most likely corresponds to the Lower Mungo unit, which contains the earliest preserved archaeological traces in the lunette (Bowler 1998; Bowler and Price 1998; Bowler et al. 2003). In the central portion of the lunette, this unit is most extensively exposed immediately upslope from the wave-cut bench incised into the Golgol unit (A). The initial Unit B lacustrine phase may have been responsible for this wave-cut erosion. Unit B is thin and laterally discontinuous in this part of the lunette, which may be attributed either to the prevailing wind regimes of the time, favouring deposition toward the southern portion of the lunette, or to the susceptibility of the sandy sediments to erosion since exposure at the surface.

Unit B is overlain by another relatively thin unit (C), comprising pale alternating well sorted mediumgrained sands and clayey medium to fine grained sands. In the latter case the clay component derives from dissolved clay pellets. The two units are distinguished by colour, clay concentration, and a weak discontinuous brownish soil containing abundant organic remains and secondary carbonates. Unit $\mathrm{C}$ corresponds most closely to the Upper Mungo unit of Bowler (1998; et al. 2003), and contains a high density of archaeological traces (Stern et al. 2013). Deposition of this unit is associated with lake levels which oscillated between lake full and drying conditions. Unit $\mathrm{C}$ appears to have been deposited very shortly after the perennial lake phase of Unit B. Deposition of Unit C initiated with the deposition of pale pelletal clays indicating a drying phase. This horizon is both discontinuous and very thin in this area in comparison with the southern part of the lunette. This may reflect a short-lived depositional phase, wind regimes favouring more southerly sediment transport, or extensive erosion since exposure. 
Unit D is a reddish-coloured, thin, and in places discontinuous horizon overlying Unit C. Beach pebbles up to $3 \mathrm{~cm}$ in diameter associated with Unit $\mathrm{D}$, indicating a lake shoreline substantially higher than that associated with Units B, C or E, abut the wave-cut cliff within the Golgol unit. Upslope from the shoreface, the Unit D deposit grades into a well sorted, medium-grained sand. Other than the iron-rich coatings on the sand grains, these sands are clean and well sorted, with no silt or clays present, and the association with the beach pebbles strongly indicates that this unit was deposited as a result of high lake levels. Unit D is not exposed in the study area but has been identified both to the north and south. This unit most likely represents a distinct, if short-lived, permanent lake phase deposited in between the Upper Mungo and Arumpo phases, and appears not to have been recognised previously (Bowler 1998). The reddish colour of this unit is distinctive and somewhat unexpected, since the high lake phases of Units $\mathrm{C}$ and $\mathrm{E}$ are pale in colour. However, the permanent lake phase deposits of Unit B are a similar colour, and it is proposed that the colour is inherited from reworked sediments of the Golgol unit, which the high lake levels may have eroded in part. Further investigations into the sedimentary characteristics of this unit are recommended.

Unit D is overlain by alternating pale sands, clayey sands and clay-rich bands which comprise the most substantial stratigraphical unit (E) in this portion of the lunette (Figure 3). Well sorted, medium-grained Sandy beds dominate this unit, indicating mostly perennial lake conditions interspersed with drying phases. The clayey sands and clay bands contain clay pellets, and clay pellets which have broken up subsequent to deposition to form coatings on the sand grains and clay-rich laminae. Unit E directly overlies the similar Unit C (Upper Mungo) in much of the area surveyed, but is distinguished from $C$ by a relative increase in sandy laminae. Unit E contains abundant and varied archaeological traces, including heat-retainer and non-heat retainer hearths, clusters of burned animal bone or eggshell and scatters of chipped stone artefacts as well as isolated finds that include grindstones and shell tools. Weak, discontinuous pedogenesis occurs as brownish discolouration within multiple laminae. Carbonate rhizomorphs form a discontinuous lag on the surface of this unit towards the lunette crest. However, these cannot be ascribed to any individual paleosol. Since no clear depositional hiatus can be identified, this sedimentary package must be interpreted as a single stratigraphical unit. This conclusion contrasts with previously published studies, which describes two similar units, Arumpo and Zanci, divided by a brown paleosol (Bowler 1998). Unit E represents the final phase of lunette deposition associated with Lake Mungo. 
Unit $\mathrm{E}$ is overlain by four stratigraphical units $(\mathrm{F}, \mathrm{H}, \mathrm{I}, \mathrm{J})$ which relate to deposition subsequent to final lake retreat. These units reflect local environmental conditions rather than palaeohydrology associated with the Willandra Creek and Murray-Darling system.

Two units (F and $\mathrm{H}$ ) comprise pale, unconsolidated, well sorted medium-grained aeolian sands deposited on the crest and lee flanks of the lunette, and derive from aeolian reactivation of the lunette sediments. Unit $\mathrm{F}$ contains a distinctive dark brown paleosol that indicates a depositional hiatus between $\mathrm{F}$ and $\mathrm{H}$. Both units were most likely deposited in response to local arid conditions. The uppermost mobile sands of Unit $\mathrm{H}$ may also reflect increased sediment availability due to overgrazing and tree-felling subsequent to European arrival. Unit F broadly correlates with the 5-15 cm thick "post-Zanci aeolian blanket" described by Dare-Edwards (1979), although it is thicker and more extensive than previously suggested. It contains archaeological traces, but in much lower density than in units B - E; they consist almost entirely of heatretainer hearths and refitting sets of stone artefacts.

Units I and $\mathrm{J}$ are brown and pale clayey sands respectively, and were both deposited by fluvial and sheetwash activity on the lakeward lunette flanks. Unit I is a poorly sorted, relatively clay-rich fine to coarse sand with a visible humic component. Unit J, by comparison, comprises poorly sorted clays through to coarse sands, but contains no organic material. The older alluvial fans of Unit I may correspond to relatively wetter conditions than exist at present, and contain hearths and stone artefacts. Unit I correlates stratigraphically to a phase of more humid conditions and dune stability proposed by Dare-Edwards (1979). Unit J represents modern sheetwash sediments that accumulate during recent intense rainfall events.

\subsection{OSL dosimetry}

371 The quartz-rich sediments from this region appear to be well suited to OSL dating. Datable grains from all samples exhibit bright, rapidly decaying signals typical of highly sensitive quartz dominated by the fast component (Figure $4 \mathrm{~b}, \mathrm{c}$ ). The majority of samples contain a high proportion of luminescent grains relative to sediments from other environments, attributed to sensitisation over multiple cycles of exposure and burial within the sedimentary system (e.g. Pietsch et al. 2008; Fitzsimmons 2011). IRSL signals are negligible, indicating no feldspar contamination of the quartz signal.

\section{Insert Figure 4 here}


In most instances, the samples yield normal distributions (Figure 4b, c; Figures S3, S4, S5). This is not unexpected considering that aeolian transport is conducive to complete bleaching of the OSL signal prior to deposition. Overdispersion ranges between 20-39\% (Table S2), with the exception of the Holocene-age samples, which yield higher overdispersion values and produce comparatively wide age distributions (Figure 4c). Wide distributions have previously been observed in MDB sediments (Lomax et al. 2007), and were attributed to proportionally high dose rate heterogeneity in sediments with very low concentrations of radiogenic elements.

\section{Insert link to Table S2 here}

Since there is no indication that the samples were incompletely bleached or mixed subsequent to deposition, the Central Age Model (CAM) of Galbraith et al. (1999) was used for age calculation, with three exceptions. Sample EVA1006, taken from Unit A (Golgol), yields a high proportion of saturated grains, and those grains accepted for final analysis produce a wide age distribution consistent with a paleosol of considerable antiquity, subject to post-depositional mixing. Consequently the age was calculated using the minimum age model (MAM) (Galbraith et al. 1999) and is considered a minimum estimate. Samples EVA1003 and EVA1007 both yielded mixed dose populations. This could be explained by the fact that EVA1003 a weakly developed paleosol. EVA1007 was collected from sediments immediately overlying the Golgol paleosol, and may contain a component of incompletely bleached older sediment. For both EVA1003 and EVA1007, the finite mixture model (Galbraith and Green 1990) was applied to extract the most likely populations (Table S3).

\section{Insert link to Table S3 here}

\subsection{OSL dose rates}

The dose rates of the samples in this study vary substantially, with total dose rates ranging from $0.50 \pm$ $0.02 \mathrm{~Gy} / \mathrm{ka}$ (EVA1012) to $2.79 \pm 0.14 \mathrm{~Gy} / \mathrm{ka}$ (EVA1005). The lowest dose rates were observed in the quartz sand-dominated sediments of Unit B (Lower Mungo) and the redeposited aeolian and alluvial sands of units F and I (respectively). The calcium carbonate-enriched Golgol unit also yielded comparatively low total dose rates. These results are not surprising, since quartz and calcium carbonate are known to contain very low concentrations of radioactive elements. By contrast, the alternating sands and clayey sands of units $\mathrm{C}$ and $\mathrm{E}$ (Upper Mungo and Arumpo/Zanci) produced the greatest range of dose rates, including the highest values, which most likely reflect differential clay content, since clay minerals contain relatively higher concentrations of radioactive elements than quartz and calcium carbonate. The 
range of dose rate values exhibited by the Lake Mungo lunette sediments suggests that variation in clay content may substantially influence the total dose rate, and may have contributed to the relatively high

416 overdispersion values which earlier studies have attributed to beta dose rate heterogeneity (Lomax et al. 2007).

\subsection{Geochronology}

420 The OSL chronology is shown in Table 2, and Figures 3 and 5. The timing of deposition of lunette sediments associated with active lake hydrology broadly follows previously published schema (e.g. Bowler et al. 2003; 2012). Our study shows that lunette deposition initiated prior to the last interglacial (marine oxygen isotope stage (MIS) 5), since Unit A (Golgol) is >141 ka. This was followed by a substantial depositional hiatus prior to the high perennial lake levels associated with deposition of Unit B (Lower Mungo) around 50-40 ka. This phase may have been of longer duration, but cannot be constrained on the basis of the three ages presented here. The oscillating lake levels and drying phase of Unit C (Upper Mungo) were established by $\sim 34 \mathrm{ka}$. The short-lived, high permanent lake phase of Unit D must therefore have been deposited sometime after $\sim 34 \mathrm{ka}$, but prior to the oldest age for Unit $\mathrm{C}$ of $\sim 25$ ka. The most substantial lunette unit (E), representing oscillating lake full and drying conditions, was deposited over MIS 2 and the LGM and spans at least 25-14 ka. The baked sediment hearths sampled for this study (368 and 403) also date to this period. Following lake retreat after $\sim 14 \mathrm{ka}$, arid conditions facilitated aeolian reworking (Unit F) at least by $\sim 8 \mathrm{ka}$. This was followed by a relatively humid phase associated with alluvial redeposition of lunette sediments during the mid-Holocene $(\sim 5-3 \mathrm{ka})$. The youngest hearth (80) dates to this period. Subsequent aeolian and alluvial reworking of lunette sediments must therefore be at most late Holocene age, and may reflect present-day conditions.

\section{Insert Figure 5 here}

\subsection{Archaeological traces}

Archaeological traces preserved within the Lake Mungo lunette include a variety of hearths, some with associated contain food remains and chipped stone artefacts, clusters of burned and fragmented animal bones or eggshell, and clusters of chipped stone artefacts (many of which include refitting sets and most of which are made from silcrete), outcrops of which are scattered throughout the region (Allen 1972; Shawcross 1998; Stern et al. 2013). Isolated finds include unworked silcrete cobbles, large silcrete cores, grindstones, shell tools and ochre. 
Systematic foot surveys of archaeological traces, undertaken to the north and south of the area studied here, indicate that evidence of human activity, while present within all stratigraphical units except for Unit A, is unevenly distributed through time (Stern et al. 2013). No traces are observed within the cemented calcareous soils of Unit A (Golgol), although this is not unexpected considering its antiquity, which predates human arrival on the continent. A lag of carbonate nodules overlying Unit A (Golgol) represents a more recent eroded land surface, amongst which fragmented heat retainers and sets of refitting artefacts lie. The heat retainers can be distinguished from the carbonate lag by darker colour and consolidated texture resulting from heat exposure. These remains are clearly much younger than Unit A, but their precise age cannot be established since they could have accumulated at any time since exposure of that surface. The highest density of archaeological traces occurs within Unit C (Upper Mungo), in the form of various types of hearths and clusters of stone artefacts and animal bones. Units B (Lower Mungo) and $\mathrm{E}$ (Arumpo/Zanci) exhibit comparable densities of activity traces per unit area of exposure, but these do not approach the density of material found in Unit C. However, because Unit E makes up the greatest volume of sediment in this part of the Mungo lunette, the activity traces from this unit predominate. Archaeological traces are also present within the sediments deposited subsequent to lake retreat, but are not as abundant or as varied as they are in lunette Units B through E. Termite heat-retainer hearths and stone artefacts are also present on the dry lake floor (Johnston and Clark 1998).

Hearth 403, located within Unit E (Arumpo/Zanci), is stratigraphically the lowest site directly dated in this study. This feature dates to between $25.0 \pm 1.2 \mathrm{ka}$ and $23.4 \pm 1.1 \mathrm{ka}$ (ca. $24 \mathrm{ka}$ ) (Figure 5). It is located on the lower lakeward flanks of the lunette, within a cluster of 39 baked sediment hearths that lie in the same stratigraphical position. Hearth 403 is one of the largest hearths in this cluster, and lies on the southern flank of a small erosional gully. The hearth cluster lies on the contact between pale sands and clayey sands within the lower portion of Unit E. A discontinuous, weakly developed brown paleosol is exposed at this contact, and indicates that these hearths, including Hearth 403, were used during a minor depositional hiatus (responsible for pedogenesis) within a period of transition from lake full to drying conditions. The association of the hearths with a depositional hiatus means that they cannot necessarily be regarded as contemporaneous features and are unlikely to represent a single, large gathering of people. It may also explain the absence of associated faunal remains, as these are unlikely to survive unless buried rapidly by sediment.

Hearth 368 lies close to the lunette crest within the upper portion of Unit E, and is constrained to 17.2 $\pm 1.5 \mathrm{ka}$ and $14.6 \pm 1.1 \mathrm{ka}$ (ca. 16-15 ka) (Figure 5). It lies within a bed of clean quartz sand, indicating lake full conditions when the hearth was used. Within age uncertainties, this suggests persistence of the 
lake up to several thousand years later than previously proposed. Hearth 368 is a well-preserved baked sediment hearth associated with a discrete scatter of burned bettong bones (a medium sized burrowing marsupial that is well-represented in the Willandra faunal record) and chipped stone artefacts struck from the same nodule of orange-brown silcrete. These include 5 pairs of refitted flakes. The baked sediment comprises a layer of cemented ash overlying a layer of oxidised sediment. A now-fragmented cobble of fine-grained sandstone beneath the cemented ash on the eroding edge of the hearth may have been one of a number of heat retainers lost through erosion. The hearth and associated debris is preserved by a layer of relatively clay-rich sediment, deposited in response to subsequent lake retreat.

Hearth 80 is stratigraphically the youngest site sampled in this study, and is exposed within the sheetwash fan Unit I, in the wall of a gully at the base of the lakeward lunette flank. The age of this feature lies between $5.2 \pm 0.3 \mathrm{ka}$ and $3.4 \pm 0.3 \mathrm{ka}$ (ca. $4 \mathrm{ka}$ ). It comprises heat retainers made from termite mounds. Unit I was deposited during a relatively humid phase subsequent to final lake retreat, and therefore hearth 80 indicates continued human presence in the area after the lake had dried out. Unfortunately, the heavy rains of the summer of 2010/2011 widened the gully and destroyed this hearth before more detailed study could be undertaken.

\section{DISCUSSION}

\subsection{Depositional history and palaeoenvironments at Lake Mungo}

Figure 6 summarises the chronostratigraphy and hypothesised lake level curve based on data from this study, compared with previously published models for the Willandra Lakes system and age estimates for Lake Mungo (Bowler 1998; Bowler et al. 2012). Our data from the less well studied central portion of the Lake Mungo lunette are generally compatible with existing models. It is important to note, however, that the correlations made in this paper are necessarily made between our data and the information published from several sections in the southern part of the lunette. As yet, large stretches of the $>30 \mathrm{~km}$ long lunette, particularly in the north and very far south, remain unstudied. Our data suggest that there is substantial spatial variability in deposition of the lunette with time. Consequently, the depositional model for the feature as a whole could be expected to evolve with additional studies.

\section{Insert Figure 6 here}

The timing of the earliest permanent lake phase, indicated by Unit A (Golgol), cannot yet be constrained reliably. Previously published TL ages for this unit range between 180-98 ka, with uncertainties of up to 
30\% (Bowler and Price 1998) (Figure 6; Table S4). Our study presents the first OSL age for these sediments, and yields a minimum age of $>141 \mathrm{ka}$. Our result suggests some inaccuracy in the earlier TL dating, which used larger aliquots and therefore yielded an averaged signal which may have included both saturated grains and material intermixed during pedogenesis. Nevertheless, Unit A (Golgol) clearly predates the last interglacial (MIS 5e). This was followed a protracted period of pedogenesis prior to deposition of Unit B (Lower Mungo).

\section{Insert link to Table S4 here}

Unit B (Lower Mungo) reflects the reinstatement of a perennial lake which persisted at least through 50 $40 \mathrm{ka}$, and possibly longer (from $\sim 62 \mathrm{ka}$; Bowler et al. 2003). Our three OSL ages from this unit correlate with previously published results (Oyston 1996; Bowler and Price 1998; Bowler et al. 2003; Bowler et al. 2012; Table S4). This high lake phase corresponds to mid-MIS 3, and is coincident with a period of increased effective precipitation in the lower MDB (Ayliffe et al. 1998; St Pierre et al. 2009) and reduced local dune activity (Lomax et al. 2011) (Figure 7d, e). Recent radiocarbon dating of the transition from Lower to Upper Mungo suggest that the lake shifted from full to oscillating conditions around $\sim 40 \mathrm{ka}$ (Bowler et al. 2012), consistent with our younger ages from this unit.

\section{Insert Figure 7 here}

Oscillating lake levels, as indicated by Unit C (Upper Mungo), were established at least by $\sim 34 \mathrm{ka}$. This age fits within the model proposed by Bowler (1998; et al. 2003, 2012), which suggested deposition of this unit to have ranged between $\sim 40-30 \mathrm{ka}$ (with the exception of one substantially younger TL age of $\sim 25 \mathrm{ka}$; Readhead 1988). The timing of deposition of this unit correlates with the development, after $\sim 34$ $\mathrm{ka}$, of large meandering channels within the Lachlan River system, thought to be influenced by increased precipitation and lower evapotranspiration in the headwaters (Kemp and Rhodes 2010). The timing also correlates with glaciation in the southeastern Australian highlands around $\sim 32$ ka (Barrows et al. 2001), and may be associated with seasonal snow melt influencing fluvial discharge to the Lachlan River and Willandra Lakes downstream. A seasonal model of oscillating lake levels may apply, at least during the latter part of this phase. Locally, linear dune activity persisted in the lower MDB, suggesting greater availability of sediment, possibly sourced from the fluvial systems (Lomax et al. 2011).

The two Mungo units (B and C) in the central portion of the lunette are very thin $(<0.5 \mathrm{~m})$, and contrast 547 with previous work from the south which indicates substantially thicker deposits (Bowler et al. 2003). 
Although we cannot preclude spatially variable erosion of lunette units in the past, deposition of these sediments may have been spatially variable along the length of the lunette. If the latter is the case, then it may have occurred as a consequence of wind regimes with a more dominant northerly component than those prevailing today. Such conditions would result in relatively thin lunette deposition in the WOCT area, and thicker deposition in the south. This hypothesis is consistent with the timing and orientation of proposed wind variations in the Naracoorte region to the southeast, based on geochemical sourcing of sedimentary deposits (Darrénougué et al. 2009). However, it cannot be confirmed at Lake Mungo without more systematic surveying of unit thickness along the lunette.

Earlier studies do not discuss the distinct red sand (Unit D) which overlies the pale laminated sediments of Unit C. Bowler (1998) described a clean sand representing a short-lived lake transgression within the base of the Arumpo unit, but did not note a colour difference, nor was it attributed to a distinct depositional phase. This unit may have been deposited so thinly in the south as to be indistinguishable from the overlying Arumpo beds. Deposition of Unit D most likely corresponds to the latter phase of substantially increased fluvial activity in the Lachlan River (Kemp and Spooner 2007; Kemp and Rhodes 2010) (Figure 7c).

Unit $\mathrm{E}$ is the thickest unit in the central portion of the Mungo lunette, and represents the final phase of lunette deposition prior to lake retreat. It deposited rapidly between $\sim 25-14 \mathrm{ka}$ - immediately prior to, during and after the LGM. The pale alternating sands and clayey sands reflect oscillating lake levels, consistent with both the Arumpo and Zanci phases of Bowler (1998; et al. 2003, 2012). Previously published chronologies propose a longer duration of deposition spanning 31-16 ka, peaking around 2319 ka within analytical uncertainties (Table S4). Our chronostratigraphy differs from the previous model suggesting two distinct units, due to the lack of paleosol preservation which would separate the sequence, and by younger ages which suggest continued lake filling and drying several millennia beyond $\sim 16$ ka. We interpret this phase as a single stratigraphical unit, with the multiple weak, discontinuous paleosols representing short-lived, local stability rather than substantial depositional hiati. The ten OSL ages for this unit lie within error of one another, and further support this model. The thickness of Unit E at WOCT contrasts with that observed at the southern end of the lunette, and may imply deposition influenced by a more westerly wind regime during MIS 2. Unit E coincides with the LGM, a period acknowledged to have been relatively colder and more arid than the present day across much of the Australian continent (Bowler 1976; Hesse et al. 2004; Fitzsimmons et al. in press). During this time, Lachlan River discharge substantially increased (Kemp and Spooner, 2007; Kemp and Rhodes, 2010). Fluvial activity most likely occurred in response to increased runoff due to reduced vegetation cover (Kemp and Rhodes, 2010), and 
increased snow melt associated with periglaciation in the highland headwaters (Barrows et al. 2001; Barrows et al. 2004). Consequently, Lake Mungo experienced regular permanent lake conditions at this time (Bowler et al. 2012). The occurrence of lake filling contrasts with aeolian activity in the surrounding dunefields, which indicate locally arid conditions (Lomax et al. 2011). The unique combination of conditions at the Willandra Lakes is likely to have had a significant influence on human foraging strategies and mobility patterns.

This study also provides, for the first time, insights into the changing conditions at Lake Mungo subsequent to final lake regression. Redeposited aeolian sediments (Unit F) suggest relatively arid conditions by the early Holocene. It is possible that these conditions were established earlier than $\sim 8 \mathrm{ka}$ (as hypothesised in Figure 8b). Dare-Edwards (1979) described a "post-Zanci aeolian unit", stratigraphically comparable with Unit F, deposited between $~ 14.5-6 \mathrm{ka}$, which supports this hypothesis. Although Unit F aeolian reactivation is consistent with Dare-Edwards' observations, our observations show more substantial sediment accumulation than previously indicated. Lateral variation in sediment thickness may be expected in response to local variations and prevailing wind regimes. Intensified regional desert aeolian activity (Figure 7d; Fitzsimmons et al. 2007; Lomax et al. 2011; Fitzsimmons and Barrows 2012), reduced fluvial output (Figure 7c; Page et al. 1996; Page et al. 2001; Kemp and Rhodes 2010), and decreased speleothem precipitation (Figure 7e; Ayliffe et al. 1998; Cohen et al. 2011) collectively indicate a reduction in effective precipitation during the Pleistocene-early Holocene transition period.

Insert Figure 8 here

The deposition of alluvial fans (Unit I) on the lakeward lunette flanks, and pedogenesis within Unit F, collectively indicate mid-Holocene amelioration of the local climate. This relatively more humid period was also proposed by Dare-Edwards (1979) on the basis of pedological evidence. He proposed two phases of Holocene pedogenesis: the first around $\sim 6-2.5$ ka under relatively humid conditions, and a later phase ( 3.5-0.5 ka) which took place under comparatively more arid, but nevertheless stable, conditions. This distinction was not observed within our study area. There is increasing evidence for relatively humid and stable climatic conditions during the Holocene within the dryland regions of Australia (Fitzsimmons et al. in press). Speleothem growth in semi-arid southeastern Australia (St Pierre et al. 2009; Quigley et al. 2010; St Pierre et al. 2012), and short-lived lake transgressions at Lakes Frome and George (Fitzsimmons and Barrows 2010; Cohen et al. 2011), are attributed to increased effective precipitation around this time. 
The relatively humid conditions at Lake Mungo persisted until at least $\sim 3 \mathrm{ka}$. Subsequently, both aeolian and fluvial or sheetwash deposition (Units $\mathrm{H}$ and $\mathrm{J}$ respectively) occurred, both of which are active, although not simultaneously. Modern erosion and deposition is a combined response to seasonal conditions, and the substantially increased availability of sediment since the initiation of pastoral activity, tree-felling and introduction of associated erosion agents such as rabbits and hard-hooved grazing animals. Consequently, although there is a strong climatic component to modern sediment deposition, it cannot be decoupled from anthropogenic influence.

\subsection{Archaeological implications for Lake Mungo}

625 The archaeological traces preserved within the lunette sediments (Allen 1972; Shawcross 1998; Stern et 626 al. 2013), as well as on the lake floor (Johnston and Clark 1998), indicate that the Lake Mungo area was 627 occupied by humans under a range of environmental conditions, including subsequent to final lake retreat. 628 Clearly the region was not abandoned completely, as was once proposed (Allen 1974). Occupation of the 629 area under variable environmental regimes is borne out by the summary of existing ages for archaeological traces at Lake Mungo and the Willandra Lakes, compared with its palaeoenvironmental history (Figure 8). However, since the previously documented archaeological record was compiled from studies of geographically and temporally scattered features, rather than from systematic studies of the density and diversity of archaeological traces in different strata and landforms, the data presented in Figure 8 should not be over-interpreted.

Systematic foot surveys of parts of the lunette suggest that the density and diversity of archaeological traces varies between the different stratigraphical units (Stern et al. 2013). This suggests a shift in when, how often, and for how long people foraged for food or gathered for ceremonial activities under varying environmental conditions. In the central Mungo lunette, the greater density of archaeological traces occurs in units corresponding to fluctuating or oscillating lake levels (Units $\mathrm{C}$ and the upper portion of E), although they are also present in units reflecting sustained lake-full conditions (Units B, D and the lower part of E; Stern et al. 2013). These results suggest that the margin of Lake Mungo was a more attractive base from which to forage for food when flood pulses regularly entered the overflow system (Stern et al. 2013), in contrast with earlier speculation (Allen 1998; Mulvaney and Kamminga 1999). When the lakes were full, fish and shellfish would have been hard to locate and would have offered limited return for the energy invested in their harvest. Conversely, phases of oscillating lake levels indicate that regular flood pulses recharged the lake system, and may have enhanced its biological productivity in much the same way that flood pulses do for floodplain wetlands (e.g. Robertson et al. 1999; Scholz et al. 2002). Those portions of the stratigraphic sequence made up of alternating lenses of 
sandy clay and clayey sands, indicative of oscillating conditions, contain as many hearths in the clays as in the sands. This suggests that it was the conditions created by oscillating lake levels that rendered the margin of Lake Mungo an attractive foraging base, perhaps in association with reduced availability of water in the wider landscape (Bowler 1998; Bowler et al. 2012). The faunal remains associated with these hearths include both terrestrial and lacustrine resources, but more detailed studies of excavated assemblages are required to assess the relative contribution of each to the diet.

Caution should be taken in interpreting differences in the density of archaeological traces per unit area of exposure in different stratigraphical units. Densities of hearths and other activity traces are influenced by sedimentation rates and the relative compression of time, as well as occupation intensity. This problem is particularly acute for the lower stratigraphic units, which are quite thin. Occupation intensity may also have varied along the length of the lunette. If these issues can be resolved at all, they cannot be resolved without systematic measurement of unit thickness along the lunette, combined with net estimates of sedimentation rates. Since net sediment accumulation may have been quite variable, this requires more precise geochronological data than presently available.

663 The stratigraphy and OSL dating of two hearth features within the artefact-rich alternating sands and 664 clayey sands of Unit E (Arumpo/Zanci) indicate that human occupation persisted under a range of 665 conditions throughout this depositional phase. Hearth 403 corresponds to occupation during a period of 666 depositional hiatus within the lunette and transition from lake full to drying conditions. By contrast, 667 hearth 368 was occupied during a high lake stand shortly after which the lake dried out. Both of the dated 668 hearths are baked sediment features, which indicate continuous adoption of this kind of hearth 669 reconstruction irrespective of palaeohydrological conditions. Baked sediment hearths are not the only 670 type of hearth found in Unit E. A variety of hearth types have been dated previously using a number of 671 methods, and many of the resulting age determinations place them in this unit (Barbetti and Polach 1972; 672 Bowler et al. 1972; Readhead 1990; Oyston 1996; Bowler 1998; Bowler and Price 1998) (Figure 8). A 673 recent compilation of radiocarbon dates for fish otoliths and shellfish cluster about the LGM (Bowler et 674 al. 2012). These are coincident with the deposition of the upper portion of Unit $\mathrm{E}$ (Arumpo/Zanci) and 675 support the hypothesis that lacustrine resources were more readily available (and possibly exploited) 676 during oscillating lake levels. This is consistent with the comparative rarity (Stern et al. 2013) and small 677 scale (Johnston 1993) of middens in the Willandra Lakes archaeological record, indicating shellfish as a 678 fallback food (Bailey 1978). Consequently, archaeology in the Willandra lakes is not a "record of 679 middens and stone artefacts", as proposed by Allen and Holdaway (2009), but rather a record of hearths 680 and the food remains and artefacts associated with them. 
The densities of archaeological traces reduce substantially within the post-lunette reactivation units, and are not as varied in character. The magnitude of this transition provides a reasonable degree of confidence that the intensity of human occupation of the lunette decreased subsequent to final lake retreat, and that the nature of occupation changed. Allen (1974) suggested that after the lakes dried out, people moved westward to the Darling River as a permanent water source, with the consequence that the Willandra lakes became part of the hinterland, visited only intermittently. However, the hearths, isolated finds and refitting sets of stone artefacts found within Units F and I indicate occupation of the lunette even when the lake was dry, and that humans spent sufficient time there to invest in the transportation of silcrete cobbles and cores to manufacture stone tools. The chronostratigraphy associated with hearth 80 indicates occupation under relatively humid conditions locally, despite a lack of lacustrine resources. The area clearly represented a viable option for occupation at this time.

\section{CONCLUSIONS}

694 This study represents the first single grain OSL chronology of the full lunette sequence at Lake Mungo, extending through lunette deposition to the reactivated units deposited subsequent to final lake retreat. Our focus on the relatively understudied central portion of the lunette highlights the potential for spatial variability in the deposition of sediments along its length. Two stratigraphical units (B and C; corresponding to the Lower and Upper Mungo phases respectively) appear to be substantially thinner in the central part of the lunette, compared with the south, and suggest deposition under wind regimes with a more northerly component during MIS 3. By comparison, the overlying unit E (correlated with Arumpo/Zanci) is substantially thicker in the central compared with the southern portion, suggesting a shift towards more westerly wind regimes during MIS 2 (including the LGM). Paleosols within this latter unit are discontinuous and weakly developed, indicating a single depositional unit, which contrasts with previous models proposing two distinct depositional phases.

705 Archaeological traces are present within the lunette throughout all stratigraphical units deposited after ca. $50 \mathrm{ka}$, indicating human occupation under a variety of palaeoenvironmental conditions, including after the final drying of the lake. The density, however, of archaeological traces varies, and may reflect changes in the intensity and patterns of human occupation in the area. Care must be taken with the attribution of artefacts to stratigraphical units. Notably, occupation of the lunette persisted during oscillating lake levels. This may have been possible due to the more ready availability of lacustrine food resources under drying phases.

\section{ACKNOWLEDGEMENTS}


714 This research was undertaken with the permission of the Elders' Council and the Technical and Scientific 6715 Advisory Committee of the Willandra Lakes Region World Heritage Area (WLRWHA). It was funded

7 both by an Australian Research Council (ARC) Discovery Project (DP1092966) and by an Australian

717 Research Council Linkage project (LP0775058), the latter in partnership with the Elders Council of the 720 Evolutionary Anthropology and the Archaeology Program at La Trobe University. Daryl Pappin, the project's Cultural Heritage Officer, and Rudy Frank, provided invaluable assistance in the field, and Steffi 722 Albert assisted with sample preparation in the OSL laboratory. We thank the Paakantyi/Barkindji, 723 Ngiyampaa and Mutthi Mutthi Elders for welcoming us into their country and for their collaboration in 
4725 TABLE CAPTIONS

5

6726

8727

Table 1. Summary of lunette stratigraphy in the central portion of the Lake Mungo lunette, comparing the 10 schema of Bowler (1998; et al., 2003) with observations made in this study. 


\section{FIGURE CAPTIONS}

Figure 1. Map of the Lake Mungo lunette within the Willandra Lakes Region World Heritage Area, including the locations of the transect and mapped area forming this study. The Lake Mungo lunette is shown in grey; major lunettes of the other Willandra lakes are shown in black.

Figure 2. (A) Location of the geological mapping and archaeological foot survey transect, Lake Mungo lunette (whole lake shown as inset). (B) Schematic cross section showing the interpreted stratigraphy in this portion of the lunette.

Figure 3. Geological map of stratigraphical boundaries, showing locations of hearths and OSL sampling locations, with age estimates. Note that since samples were mostly collected from residuals, the stratigraphical unit exposed at the surface does not necessarily reflect the units from which samples were collected at individual sites. Sample EVA1010 was collected just to the north of the mapped area, from a surface residual of Unit B (Lower Mungo) sediments. Age estimates are shown in stratigraphical order. As additional geochronological data from individual hearths become available, refinements to the geological map may be possible.

Figure 4. Representative OSL characteristics of sediments from the central part of the Lake Mungo lunette: (A) Preheat plateau for sample L-EVA1002 (Unit E/Arumpo); Radial plots showing dose distributions, and (as inset) natural OSL decay and dose-response curves, for samples (B) L-EVA1002 and (C) L-EVA1000 (Unit I/alluvial fan) respectively. The shaded area corresponds to $2 \sigma$ from the $\mathrm{D}_{\mathrm{e}}$, calculated using the Central Age Model of Galbraith et al. (1999). The radial plots illustrate the distributions of ages for each aliquot (right-hand radial $y$-axis) relative to precision (x-axis).

Figure 5. Schematic cross section showing the chronostratigraphy, and position of sampled hearths, of the transect studied.

Figure 6. (A) Lake Mungo palaohydrology (shown in turquoise) and chronostratigraphy interpreted from the results of this study, illustrated as an age-ranked plot and lake-level diagram. The interpreted timing of pedogenesis is indicated by pale grey shading. The ages of individual hearths are shown. (B) Willandra Lakes lake level curve (shown in blue), based on data from Bowler et al. (2012; for period 40-10 ka) and Bowler (1998; for >40 ka). The published combined ages for the Lake Mungo lunette ( $\mathrm{n}=85$; Readhead 1988; Bell 1991; Oyston 1996; Bowler 1998; Bowler and Price 1998; Bowler et al. 2003; Bowler et al. 2012) are also illustrated as a probability density function illustrated with a single black line, with low precision ages for the Golgol unit shown as individual age estimates. The proposed chronology for pedogenesis of Bowler (1998) is indicated by pale grey shading. Global marine oxygen isotope chronozones (Martinson et al. 1987) are shown for context.

Figure 7. (A) Lake Mungo palaohydrology (shown in turquoise) and chronostratigraphy interpreted from the results of this study, illustrated as an age-ranked plot and lake-level diagram. The ages of individual 
hearths are shown. (B) Willandra Lakes lake level curve (shown in blue), based on data from Bowler et al. (2012; for period 40-10 ka) and Bowler (1998; for >40 ka). The published combined ages for the Lake Mungo lunette (n=85; Readhead 1988; Bell 1991; Oyston 1996; Bowler 1998; Bowler and Price 1998; Bowler et al. 2003; Bowler et al. 2012) are also illustrated as a probability density function illustrated with a single black line, with low precision ages for the Golgol unit shown as individual age estimates. (C) records of fluvial activity in the Lachlan River (Kemp and Rhodes 2010); (D) records of subparabolic and linear desert dune activity in the western Murray-Darling Basin (Lomax et al. 2011); (E) records of speleothem growth in the Naracoorte Caves (Ayliffe et al. 1998). Global marine oxygen isotope chronozones (Martinson et al. 1987) are shown for context.

Figure 8. Integration of the Lake Mungo palaeoenvironmental record with the chronology of archaeological traces, 0-60 ka. (A) Willandra Lakes lake level curve (shown in grey), based on data from Bowler et al. (2012; for period 40-10 ka) and Bowler (1998; for >40 ka). The published combined ages for the Lake Mungo lunette (Readhead 1988; Bell 1991; Oyston 1996; Bowler 1998; Bowler and Price 1998; Bowler et al. 2003; Bowler et al. 2012) are also illustrated as a probability density function illustrated with a single black line; (B) Lake Mungo palaeoenvironmental summary primarily based on the results of this study, and including an age-ranked plot of OSL ages with the ages of hearth features 80 , 368 and 403; (C) dates of individual archaeological traces at Lake Mungo, including hearths containing animal remains (Bowler 1998; Oyston 1996; Bowler and Price 1998), the Mungo I and III burials (Bowler et al. 2003), and hearth features along the southern half of the lunette (Bowler et al. 1972; Barbetti and Polach 1973; Readhead 1990; Bowler 1998). Note that these are only the dated features, and are not a comprehensive survey of all archaeological traces on the lunette; (D) age of the Willandra trackways (Webb et al. 2006) and the age range for the WLH50 human remains (Grün et al. 2011), both located to the north of Lake Mungo between Lakes Leaghur and Garnpung. 


\section{REFERENCES}

Adamiec, G., Aitken, M., 1998. Dose-rate conversion factors: update. Ancient TL 16, 37-50.

Adams, G., Mortlock, A., 1974. Thermoluminescence dating of baked sand from fire hearths at Lake Mungo, New South Wales. Archaeology and Physical Anthropology in Oceania 9, 236.

Allen, H., 1972. Where the crow flies backwards: man and land in the Darling Basin. PhD thesis, Australian National University, Canberra.

Allen, H., 1974. The Bagundji of the Darling Basin: cereal gatherers in an uncertain environment. World Archaeology 5, 309-322.

Allen, H., 1998. Reinterpreting the 1969-1972 Willandra Lakes archaeological surveys. Archaeology in Oceania 33, 207-220.

Allen, H., Holdaway, S.J., 2009. The Archaeology of Mungo and the Willandra Lakes: Looking Back, Looking Forward. Archaeology in Oceania 44, 96-106.

Ayliffe, L.K., Marianelli, P.C., Moriarty, K.C., Wells, R.T., McCulloch, M.T., Mortimer, G.E., Hellstrom, J.C., 1998. 500ka precipitation record from southeastern Australia: Evidence for interglacial relative aridity. Geology 26, 147-150.

Bailey, G.N., 1978. Shell middens as indicators of postglacial economies: a territorial perspective, in: Mellars, P.A. (Ed.) The Early Postglacial Settlement of Northern Europe. Duckworth, London, pp. 37-63.

Barbetti, M. Polach, H., 1973. ANU Radiocarbon date list V. Radiocarbon 15, 241-251.

Barrows, T.T., Stone, J.O., Fifield, L.K., 2004. Exposure ages for Pleistocene periglacial deposits in Australia. Quaternary Science Reviews 23, 697-708.

Barrows, T.T., Stone, J.O., Fifield, L.K., Creswell, R.G., 2001. Late Pleistocene glaciation of the Kosciuszko Massif, Snowy Mountains, Australia. Quaternary Research 55, 179-189.

Bateman, M.D., Frederick, C.D., Jaiswal, M.K., Singhvi, A.K., 2003. Investigations into the potential effects of pedoturbation on luminescence dating. Quaternary Science Reviews 22, 1169-1176.

Bell, W.T., 1991. Thermoluminescence dates for the Lake Mungo aboriginal fireplaces and the implications for radiocarbon dating. Archaeometry 33, 43-50.

Botter-Jensen, L., 1997. Luminescence techniques: instrumentation and methods. Radiation Measurements 27, 749-768.

Botter-Jensen, L., Bulur, E., Duller, G.A.T., Murray, A.S., 2000. Advances in luminescence instrument systems. Radiation Measurements 32, 523-528.

Bowler, J.M., Gillespie, R., Johnston, H., Boljkovac, K., 2012. Wind v water: Glacial maximum records from the Willandra Lakes, in: Haberle, S., David, B. (Eds.) Peopled landscapes: archaeological and biogeographic approaches to landscapes. The Australian National University, Canberra, Terra Australis 34, pp. 271-296.

Bowler, J.M., Thorne, A., 1976. Human remains from Lake Mungo: Discovery and excavation of Lake Mungo III, in: Kirk, R., Thorne, A. (Eds.) The origin of the Australians. Australian Institute of Aboriginal studies, Canberra, pp. 127-138.

Bowler, J.M., 1971. Pleistocene salinities and climate change. Evidence from lakes and lunettes in southeastern Australia, in: Mulvaney, D.J., Golson, J. (Eds.) Aboriginal Man and Environment in Australia. Australian National University, Canberra.

Bowler, J.M., 1973. Clay dunes: their occurrence, formation and environmental significance. Earth Science Reviews 9, 315-338.

Bowler, J.M., 1976. Aridity in Australia: Age, origins and expression in aeolian landforms and sediments. Earth Science Reviews 12, 279-310.

Bowler, J.M., 1983. Lunettes as indices of hydrologic change: A review of the Australian evidence. Proceedings of the Royal Society of Victoria 95, 147-168.

Bowler, J.M., 1998. Willandra Lakes revisited: environmental framework for human occupation. Archaeology in Oceania 33, 120-155. 
Bowler, J.M., Johnston, H., Olley, J.M., Prescott, J.R., Roberts, R.G., Shawcross, R., Spooner, N.A., 2003. New ages for human occupation and climatic change at Lake Mungo, Australia. Nature 421, 837-840.

Bowler, J.M., Jones, R., Allen, H., Thorne, A.G., 1970. Pleistocene human remains from Australia: A living site and human cremation from Lake Mungo, western New South Wales. World Archaeology 2, 39-60.

Bowler, J.M., Kotsonis, A., Lawrence, C.R., 2006. Environmental evolution of the Mallee region, Western Murray Basin. Proceedings of the Royal Society of Victoria 118, 161-210.

Bowler, J.M., Magee, J.W., 1978. Geomorphology of the Mallee region in semi-arid northern Victoria and western New South Wales. Proceedings of the Royal Society of Victoria 90, 5-25.

Bowler, J.M., Price, D.M., 1998. Luminescence dates and stratigraphical analyses at Lake Mungo: review and new perspectives. Archaeology in Oceania 33, 156-168.

Bowler, J.M., Thorne, A.G., Polach, H.A., 1972. Pleistocene Man in Australia: Age and Significance of the Mungo Skeleton. Nature 240, 48-50.

Chappell, J., Head, J., Magee, J.W., 1996. Beyond the radiocarbon limit in Australian archaeology and Quaternary research. Antiquity 70, 543-552.

Cohen, T.J., Nanson, G.C., Jansen, J.D., Jones, B.G., Jacobs, Z., Treble, P., Price, D.M., May, J.-H., Smith, A.M., Ayliffe, L.K., Hellstrom, J.C., 2011. Continental aridification and the vanishing of Australia's megalakes. Geology 39, 167-170.

Dare-Edwards, A.J., 1979. Late Quaternary soils on clay dunes of the Willandra Lakes, New South Wales. PhD thesis, Australian National University.

Darrénougué, N., De Deckker, P., Fitzsimmons, K.E., Norman, M.D., Reed, L., van der Kaars, S., Fallon, S., 2009. A late Pleistocene record of aeolian sedimentation in Blanche Cave, Naracoorte, South Australia. Quaternary Science Reviews 28, 2600-2615.

Fanning, P.C., Holdaway, S.J., 2002. Using geospatial technologies to understand prehistoric human/landscape interaction in arid Australia. Arid lands newsletter, Office of arid lands studies, University of Arizona, Tuscon 51, 10.

Fanning, P.C., Holdaway, S.J., Rhodes, E.J., 2007. A geomorphic framework for understanding the surface archaeological record in arid environments. Geodinimica Acta 20, 275-286.

Fitzsimmons, K.E., 2011. An assessment of the luminescence sensitivity of Australian quartz with respect to sediment history. Geochronometria 38, 199-208.

Fitzsimmons, K.E., Barrows, T.T., 2010. Holocene hydrologic variability in temperate southeastern Australia: An example from Lake George, New South Wales. The Holocene 20, 585-597.

Fitzsimmons, K.E., Barrows, T.T., 2012. Late Pleistocene aeolian reactivation downwind of the Naracoorte East range, South Australia. Zeitschrift für Geomorphologie 56, 225-237.

Fitzsimmons, K.E., Cohen, T.J., Hesse, P.P., Jansen, J., Nanson, G.C., May, J.-H., Barrows, T.T., Haberlah, D., Hilgers, A., Kelly, T., Larsen, J., Lomax, J., Treble, P., in press. Late Quaternary palaeoenvironmental change in the Australian drylands: a synthesis. Quaternary Science Reviews. DOI: 10.1016/j.quascirev.2012.09.007

Fitzsimmons, K.E., Rhodes, E.J., Magee, J.W., Barrows, T.T., 2007. The timing of linear dune activity in the Strzelecki and Tirari Deserts, Australia. Quaternary Science Reviews 26, 2598-2616.

Galbraith, R.F., Green, P.F., 1990. Estimating the component ages in a finite mixture. Nuclear Tracks and Radiation Measurements 17, 197-206.

Galbraith, R.F., Roberts, R.G., Laslett, G.M., Yoshida, H., Olley, J.M., 1999. Optical dating of single and multiple grains of quartz from Jinmium rock shelter, northern Australia. Part 1, Experimental design and statistical models. Archaeometry 41, 339-364.

Gillespie, R., 1997. Burnt and Unburnt Carbon: dating charcoal and burnt bone from the Willandra Lakes, Australia. Radiocarbon 39, 239-250.

Gillespie, R., 1998. Alternative timescales: a critical review of Willandra Lakes dating. Archaeology in Oceania 33, 169-182. 
Grün, R., Spooner, N., Magee, J.W., Thorne, A., Simpson, J., Yan, G., Mortimer, G., 2011. Stratigraphy and chronology of the WLH 50 human remains, Willandra Lakes World Heritage Area, Australia. Journal of Human Evolution 60, 597-604.

Hesse, P.P., Magee, J.W., van der Kaars, S., 2004. Late Quaternary climates of the Australian arid zone: A review. Quaternary International 118-119, 87-102.

Hills, E.S., 1940. The lunette: a new land form of aeolian origin. Australian Geographer 3, 5-21.

Jacobs, Z., Roberts, R.G., 2007. Advances in optically stimulated luminescence dating of individual grains of quartz from archeological deposits. Evolutionary Anthropology: Issues, News, and Reviews 16, 210-223.

Johnston, H., 1993. Pleistocene shell middens of the Willandra Lakes, in: Smith, M., Spriggs, M., Fankhauser, B. (Eds.) Sahul in Review: Pleistocene archaeology in Australia, New Guinea and Island Melanesia. Department of Prehistory, Research School of Pacific Studies, Australian National University, Canberra, pp. 197-203.

Johnston, H., Clark, P., 1998. Willandra Lakes archaeological investigations 1968-98. Archaeology in Oceania 33, 105-119.

Kemp, J., Rhodes, E.J., 2010. Episodic fluvial activity of inland rivers in southeastern Australia: Palaeochannel systems and terraces of the Lachlan River. Quaternary Science Reviews 29, 732752.

Kemp, J., Spooner, N.A., 2007. Evidence for regionally wet conditions before the LGM in southeast Australia: OSL ages from a large palaeochannel in the Lachlan Valley. Journal of Quaternary Science 22, 423-427.

Lomax, J., Hilgers, A., Radtke, U., 2011. Palaeoenvironmental change recorded in the palaeodunefields of the western Murray Basin, South Australia - New data from single grain OSL-dating. Quaternary Science Reviews 30, 723-736.

Lomax, J., Hilgers, A., Twidale, C.R., Bourne, J.A., Radtke, U., 2007. Treatment of broad palaeodose distributions in OSL dating of dune sands from the western Murray Basin, South Australia. Quaternary Geochronology 2, 51-56.

Martinson, D.G., Pisias, N.G., Hays, J.D., Imbrie, J., Moore, T.C., Shackleton, N.J., 1987. Age dating and the Orbital Theory of the Ice Ages: Development of a high resolution 0 to 300,000-year chronostratigraphy. Quaternary Research 27, 1-29.

Mejdahl, V., 1979. Thermoluminescence dating: beta-dose attenuation in quartz grains. Archaeometry 21, 61-72.

Mortlock, A., 1974. Archaeometry at Lake Mungo, New South Wales. The Australian Physicist 11, 213215.

Mulvaney, D.J., Bowler, J.M., 1981. Lake Mungo and the Willandra Lakes, in: The Heritage of Australia: the Illustrated Register of the National Estate. Macmillan, Sydney.

Mulvaney, D.J., Kamminga, J., 1999. Prehistory of Australia. Allen and Unwin, Sydney.

Murray, A.S., Wintle, A.G., 2000. Luminescence dating of quartz using an improved single-aliquot regenerative-dose protocol. Radiation Measurements 32, 57-73.

Murray, A.S., Wintle, A.G., 2003. The single aliquot regenerative dose protocol: potential for improvements in reliability. Radiation Measurements 37, 377-381.

Olley, J.M., Roberts, R.G., Yoshida, H., Bowler, J.M., 2006. Single-grain optical dating of grave-infill associated with human burials at Lake Mungo, Australia. Quaternary Science Reviews 25, 24692474.

Oyston, B., 1996. Thermoluminescence age determinations for the Mungo III human burial, Lake Mungo, Southeastern Australia. Quaternary Science Reviews 15, 739-749.

Page, K.J., Dare-Edwards, A.J., Owens, J.W., Frazier, P.S., Kellett, J., Price, D.M., 2001. TL chronology and stratigraphy of riverine source bordering sand dunes near Wagga Wagga, New South Wales, Australia. Quaternary International 83-85, 187-193.

Page, K.J., Nanson, G.C., Price, D., 1996. Chronology of Murrumbidgee river palaeochannels on the Riverine Plain, southeastern Australia. Journal of Quaternary Science 11, 311-326. 
Pietsch, T.J., Olley, J.M., Nanson, G.C., 2008. Fluvial transport as a natural luminescence sensitiser of quartz. Quaternary Geochronology 3, 365-376.

Prescott, J.R., Hutton, J.T., 1994. Cosmic ray contributions to dose rates for luminescence and ESR dating: Large depths and long term variations. Radiation Measurements 23, 497-500.

Quigley, M.C., Horton, T., Hellstrom, J.C., Cupper, M.L., Sandiford, M., 2010. Holocene climate change in arid Australia from speleothem and alluvial records. The Holocene 20, 1093-1104.

Readhead, M.L., 1988. Thermoluminescence dating study of quartz in aeolian sediments from southeast Australia. Quaternary Science Reviews 7, 257-264.

Readhead, M.L., 1990. Thermoluminescence dating of sediments from Lake Mungo and Nyah West, in: Gillespie, R. (Ed.) Quaternary dating workshop. Australian National University, Canberra, pp. 35-37.

Robertson, A.I., Bunn, S.E., Walker, F., Boon, I., 1999. Sources, sinks and transformations of organic carbon in Australia flood plain rivers. Marine and Freshwater Research 50, 813-829.

Rodnight, H., 2008. How many equivalent dose values are needed to obtain a reproducible distribution? Ancient TL 26, 3-10.

Scholz, O., Gawne, B., Ebner. B., Ellis, I., 2002. The effects of drying and re-flooding on nutrient availability in ephemeral deflation basin lakes in western New south Wales. River Research and its Applications 18, 185-196.

Shawcross, W., 1998. Archaeological excavations at Mungo. Archaeology in Oceania 33, 183-200.

St Pierre, E., Zhao, J.-X., Feng, Y.-X., Reed, E., 2012. U-series dating of soda straw stalactites from excavated deposits: method development and application to Blanche Cave, Naracoorte, South Australia. Journal of Archaeological Science 39, 922-930.

St Pierre, E., Zhao, J.-X., Reed, E., 2009. Expanding the utility of Uranium-series dating of speleothems for archaeological and palaeontological applications. Journal of Archaeological Science 36, 14161423.

Stern, N., 2008. Stratigraphy, depositional environments and palaeolandscape reconstruction in landscape archaeology, in: David, B., Thomas, J. (Eds.) Handbook of landscape archaeology. Left Coast Press, Walnut Creek, California, pp. 365-378.

Stern, N., Tumney, J., Fitzsimmons, K.E., Kajewski, P., 2013. Strategies for investigating human responses to changes in landscape and climate at Lake Mungo in the Willandra Lakes, southeast Australia, in: Frankel, D., Webb, J., Lawrence, S. (Eds.) Archaeology in environment and technology: Intersections and Transformations. Routledge, pp. 31-50.

Thorne, A., Grün, R., Mortimer, G., Spooner, N.A., Simpson, J.J., McCulloch, M., Taylor, L., Curnoe, D., 1999. Australia's oldest human remains: age of the Lake Mungo 3 skeleton. Journal of Human Evolution 36, 591-612.

Tumney, J., 2011. Environment, landscape and stone technology at Lake Mungo, southwest New South Wales, Australia. PhD thesis, La Trobe University.

Webb, S., 1989. The Willandra Lakes hominids. Department of Prehistory, Research School of Pacific Studies, Australian National University, Canberra.

Webb, S., Cupper, M.L., Robins, R., 2006. Pleistocene human footprints from the Willandra Lakes, southeastern Australia. Journal of Human Evolution 50, 405-413.

Young, A.R.M., Young, R., 2002. Soils in the Australian landscape. Oxford University Press, Melbourne. 
Table 1. Summary of lunette stratigraphy in the central portion of the Lake Mungo lunette, comparing the schema of Bowler (1998; et al., 2003) with observations made in this study.

\begin{tabular}{|c|c|c|c|c|}
\hline \multicolumn{2}{|c|}{ Stratigraphic unit } & \multirow[t]{2}{*}{ Description } & \multirow[t]{2}{*}{ Munsell colour } & \multirow[t]{2}{*}{ OSL samples } \\
\hline $\begin{array}{l}\text { This } \\
\text { study }\end{array}$ & Bowler & & & \\
\hline $\mathrm{J}$ & - & $\begin{array}{l}\text { Modern fluvial gullying and } \\
\text { sheetwash deposits on the } \\
\text { lakeward flanks of the lunette. } \\
\text { Pale brown fine clayey sand. }\end{array}$ & $\begin{array}{l}10 Y R ~ 7 / 3 \text { (very pale } \\
\text { brown) }\end{array}$ & - \\
\hline $\mathrm{H}$ & - & $\begin{array}{l}\text { Modern aeolian reactivation } \\
\text { on the crest and lee flanks of } \\
\text { the lunette. Well sorted, pale } \\
\text { medium sand. }\end{array}$ & $\begin{array}{l}\text { 10YR } 7 / 3 \text { (very pale } \\
\text { brown) }\end{array}$ & - \\
\hline I & - & $\begin{array}{l}\text { Alluvial fans on the lakeward } \\
\text { flanks of the lunette, } \\
\text { comprising brown clayey sands } \\
\text { with humic component. }\end{array}$ & $\begin{array}{l}\text { 10YR } 7 / 3 \text { (very pale } \\
\text { brown) }\end{array}$ & $\begin{array}{l}\text { EVA1000 } \\
\text { EVA1001 }\end{array}$ \\
\hline $\mathrm{F}$ & & $\begin{array}{l}\text { Aeolian sands on the crest and } \\
\text { lee flanks of the lunette, } \\
\text { overprinted by a characteristic } \\
\text { brown sandy soil. Well sorted, } \\
\text { pale medium sand. }\end{array}$ & $\begin{array}{l}\text { 10YR 5/4 (yellowish } \\
\text { brown) }\end{array}$ & EVA1017 \\
\hline \multirow[t]{2}{*}{$\mathrm{E}$} & Zanci & \multirow[b]{2}{*}{$\begin{array}{l}\begin{array}{l}\text { Alternating pale sands and } \\
\text { clayey sands } \\
\text { (containing }\end{array} \\
\text { pelletal clays), corresponding } \\
\text { to oscillating lake levels. } \\
\text { Contains multiple spatially } \\
\text { discontinuous, weakly } \\
\text { developed soils within various } \\
\text { different beds throughout the } \\
\text { sequence. Sand lamina } \\
\text { comprise well sorted fine to } \\
\text { medium sands; clayey sands } \\
\text { contain clay pellets, clay bands } \\
\text { developed from dissolved clay } \\
\text { pellets, and clay coatings on } \\
\text { the dominant fine to medium } \\
\text { grained sand grains. }\end{array}$} & \multirow{2}{*}{$\begin{array}{l}\text { 10YR } 7 / 4 \text { (very pale } \\
\text { brown) }\end{array}$} & \multirow[b]{2}{*}{$\begin{array}{l}\text { EVA1002 } \\
\text { EVA1003 } \\
\text { EVA1004 } \\
\text { EVA1005 } \\
\text { EVA1008 } \\
\text { EVA1009 } \\
\text { EVA1011 } \\
\text { EVA1014 } \\
\text { EVA1015 } \\
\text { EVA1016 }\end{array}$} \\
\hline & Arumpo & & & \\
\hline $\mathrm{D}$ & - & $\begin{array}{l}\text { Thin, steeply dipping red } \\
\text { sandy unit, with beach pebbles } \\
\text { on the lakeward flank, } \\
\text { indicating permanent high lake } \\
\text { levels. Well sorted, red } \\
\text { medium sand. No clay. }\end{array}$ & 2.5YR 6/8 light red & - \\
\hline $\mathrm{C}$ & $\begin{array}{l}\text { Upper } \\
\text { Mungo }\end{array}$ & $\begin{array}{l}\text { Thin, discontinuously exposed } \\
\text { alternating pale sands and } \\
\text { clayey sands (containing } \\
\text { pelletal clays), corresponding } \\
\text { to oscillating lake levels. Weak, } \\
\text { discontinuous brown soil. }\end{array}$ & $\begin{array}{l}10 \mathrm{YR} 7 / 4 \text { very pale } \\
\text { brown }\end{array}$ & EVA1013 \\
\hline
\end{tabular}




\begin{tabular}{|c|c|c|c|c|}
\hline & & $\begin{array}{l}\text { Contains hearths with fish } \\
\text { remains. Sand lamina comprise } \\
\text { well sorted fine to medium } \\
\text { sands; clayey sands contain } \\
\text { clay pellets, clay bands } \\
\text { developed from dissolved clay } \\
\text { pellets, and clay coatings on } \\
\text { the dominant fine to medium } \\
\text { grained sand grains. }\end{array}$ & & \\
\hline $\mathrm{B}$ & $\begin{array}{l}\text { Lower } \\
\text { Mungo }\end{array}$ & $\begin{array}{l}\text { Thin unit of red beach sands } \\
\text { corresponding to permanent } \\
\text { high lake levels. Weak, } \\
\text { discontinuous brownish soil. } \\
\text { Contains the oldest known } \\
\text { human remains (Bowler et al. } \\
\text { 2003). Well sorted, red } \\
\text { medium sand. No clay. }\end{array}$ & 2.5YR 6/8 light red & $\begin{array}{l}\text { EVA1007 } \\
\text { EVA1010 } \\
\text { EVA1012 }\end{array}$ \\
\hline $\mathrm{A}$ & Golgol & $\begin{array}{l}\text { Red indurated medium sands } \\
\text { with strong carbonate paleosol } \\
\text { development, reflecting lake } \\
\text { full conditions followed by } \\
\text { intensive pedogenesis. } \\
\text { Formation of wave-cut cliff } \\
\text { during subsequent high lake } \\
\text { levels results in a prominent } \\
\text { feature along central portion } \\
\text { of lunette. }\end{array}$ & 2.5YR 7/8 light red & EVA1006 \\
\hline
\end{tabular}


1 Table 2. Equivalent dose $\left(\mathrm{D}_{\mathrm{e}}\right)$, dose rate data and OSL age estimates for the Lake Mungo lunette

2 transect.

\begin{tabular}{|c|c|c|c|c|c|c|c|c|c|}
\hline $\begin{array}{l}\text { Sample } \\
\text { code }\end{array}$ & $\begin{array}{l}\text { Depth } \\
\text { (m) }\end{array}$ & De (Gy) & $\begin{array}{l}\text { Water } \\
\text { content } \\
(\%)\end{array}$ & K (\%) & $\mathrm{U}(\mathrm{ppm})$ & $\begin{array}{l}\text { Th } \\
(\mathrm{ppm})\end{array}$ & $\begin{array}{l}\text { Cosmic } \\
\text { dose rate } \\
(\mathrm{Gy} / \mathrm{ka})\end{array}$ & $\begin{array}{l}\text { Total } \\
\text { dose rate } \\
(\mathrm{Gy} / \mathrm{ka})\end{array}$ & Age (ka) \\
\hline EVA1000 & $\begin{array}{l}1.1 \pm \\
0.1\end{array}$ & $3.1 \pm 0.2^{\mathrm{a}}$ & $5 \pm 3$ & $\begin{array}{l}0.40 \pm \\
0.02\end{array}$ & $\begin{array}{l}0.69 \pm \\
0.04\end{array}$ & $\begin{array}{l}2.81 \pm \\
0.14\end{array}$ & $0.18 \pm 0.02$ & $\begin{array}{l}0.91 \pm \\
0.03\end{array}$ & $3.4 \pm 0.3$ \\
\hline EVA1001 & $\begin{array}{l}1.2 \pm \\
0.1\end{array}$ & $7.5 \pm 0.3^{\mathrm{a}}$ & $8 \pm 3$ & $\begin{array}{l}0.79 \pm \\
0.04\end{array}$ & $\begin{array}{l}1.12 \pm \\
0.06\end{array}$ & $\begin{array}{l}4.50 \pm \\
0.23\end{array}$ & $0.18 \pm 0.01$ & $\begin{array}{l}1.44 \pm \\
0.06\end{array}$ & $5.2 \pm 0.3$ \\
\hline EVA1002 & $\begin{array}{l}0.6 \pm \\
0.0\end{array}$ & $37.4 \pm 1.0^{\mathrm{a}}$ & $5 \pm 3$ & $\begin{array}{l}0.82 \pm \\
0.04\end{array}$ & $\begin{array}{l}1.02 \pm \\
0.05\end{array}$ & $\begin{array}{l}4.50 \pm \\
0.23\end{array}$ & $0.20 \pm 0.02$ & $\begin{array}{l}1.50 \pm \\
0.06\end{array}$ & $25.0 \pm 1.2$ \\
\hline EVA1003 & $\begin{array}{l}1.5 \pm \\
0.2\end{array}$ & $49.3 \pm 1.0^{\mathrm{b}}$ & $6 \pm 3$ & $\begin{array}{l}1.29 \pm \\
0.07\end{array}$ & $\begin{array}{l}1.03 \pm \\
0.05\end{array}$ & $\begin{array}{l}7.10 \pm \\
0.36\end{array}$ & $0.20 \pm 0.03$ & $\begin{array}{l}2.11 \pm \\
0.09\end{array}$ & $23.4 \pm 1.1$ \\
\hline EVA1004 & $\begin{array}{l}1.1 \pm \\
0.1\end{array}$ & $33.7 \pm 2.5^{a}$ & $9 \pm 4$ & $\begin{array}{l}1.31 \pm \\
0.07\end{array}$ & $\begin{array}{l}0.75 \pm \\
0.04\end{array}$ & $\begin{array}{l}6.60 \pm \\
0.33\end{array}$ & $0.18 \pm 0.02$ & $\begin{array}{l}1.96 \pm \\
0.09\end{array}$ & $17.2 \pm 1.5$ \\
\hline EVA1005 & $\begin{array}{l}1.0 \pm \\
0.1\end{array}$ & $40.8 \pm 2.2^{\mathrm{a}}$ & $13 \pm 4$ & $\begin{array}{l}2.08 \pm \\
0.10\end{array}$ & $\begin{array}{l}1.21 \pm \\
0.06\end{array}$ & $\begin{array}{l}8.47 \pm \\
0.42\end{array}$ & $0.19 \pm 0.02$ & $\begin{array}{l}2.79 \pm \\
0.14\end{array}$ & $14.6 \pm 1.1$ \\
\hline EVA1006 & $\begin{array}{l}0.5 \pm \\
0.1\end{array}$ & $144 \pm 35^{c}$ & $4 \pm 3$ & $\begin{array}{l}0.54 \pm \\
0.03\end{array}$ & $\begin{array}{l}0.48 \pm \\
0.02\end{array}$ & $\begin{array}{l}3.07 \pm \\
0.15\end{array}$ & $0.20 \pm 0.02$ & $\begin{array}{l}1.02 \pm \\
0.04\end{array}$ & $141 \pm 35$ \\
\hline EVA1007 & $\begin{array}{l}0.1 \pm \\
0.0\end{array}$ & $45.0 \pm 0.9^{b}$ & $3 \pm 2$ & $\begin{array}{l}0.59 \pm \\
0.03\end{array}$ & $\begin{array}{l}0.63 \pm \\
0.03\end{array}$ & $\begin{array}{l}3.53 \pm \\
0.18\end{array}$ & $0.21 \pm 0.08$ & $\begin{array}{l}1.15 \pm \\
0.09\end{array}$ & $39.0 \pm 3.3$ \\
\hline EVA1008 & $\begin{array}{l}0.4 \pm \\
0.0\end{array}$ & $50.9 \pm 2.2^{a}$ & $6 \pm 3$ & $\begin{array}{l}1.37 \pm \\
0.07\end{array}$ & $\begin{array}{l}1.02 \pm \\
0.05\end{array}$ & $\begin{array}{l}6.13 \pm \\
0.31\end{array}$ & $0.20 \pm 0.02$ & $\begin{array}{l}2.11 \pm \\
0.09\end{array}$ & $24.1 \pm 1.5$ \\
\hline EVA1009 & $\begin{array}{l}2.2 \pm \\
0.1\end{array}$ & $14.5 \pm 0.6^{\mathrm{a}}$ & $3 \pm 2$ & $\begin{array}{l}0.28 \pm \\
0.01\end{array}$ & $\begin{array}{l}0.48 \pm \\
0.02\end{array}$ & $\begin{array}{l}2.08 \pm \\
0.10\end{array}$ & $0.16 \pm 0.01$ & $\begin{array}{l}0.62 \pm \\
0.02\end{array}$ & $23.4 \pm 1.2$ \\
\hline EVA1010 & $\begin{array}{l}1.1 \pm \\
0.1\end{array}$ & $47.5 \pm 1.9^{\mathrm{a}}$ & $3 \pm 2$ & $\begin{array}{l}0.39 \pm \\
0.02\end{array}$ & $\begin{array}{l}0.76 \pm \\
0.04\end{array}$ & $\begin{array}{l}2.96 \pm \\
0.15\end{array}$ & $0.18 \pm 0.02$ & $\begin{array}{l}0.93 \pm \\
0.03\end{array}$ & $51.0 \pm 2.7$ \\
\hline EVA1011 & $\begin{array}{l}1.6 \pm \\
0.1\end{array}$ & $30.2 \pm 1.6^{a}$ & $3 \pm 2$ & $\begin{array}{l}0.64 \pm \\
0.03\end{array}$ & $\begin{array}{l}0.80 \pm \\
0.04\end{array}$ & $\begin{array}{l}3.41 \pm \\
0.17\end{array}$ & $0.17 \pm 0.01$ & $\begin{array}{l}1.19 \pm \\
0.04\end{array}$ & $25.3 \pm 1.7$ \\
\hline EVA1012 & $\begin{array}{l}2.8 \pm \\
0.0\end{array}$ & $20.0 \pm 0.6^{a}$ & $3 \pm 2$ & $\begin{array}{l}0.19 \pm \\
0.01\end{array}$ & $\begin{array}{l}0.33 \pm \\
0.02\end{array}$ & $\begin{array}{l}1.37 \pm \\
0.07\end{array}$ & $0.15 \pm 0.01$ & $\begin{array}{l}0.50 \pm \\
0.02\end{array}$ & $40.0 \pm 1.8$ \\
\hline
\end{tabular}




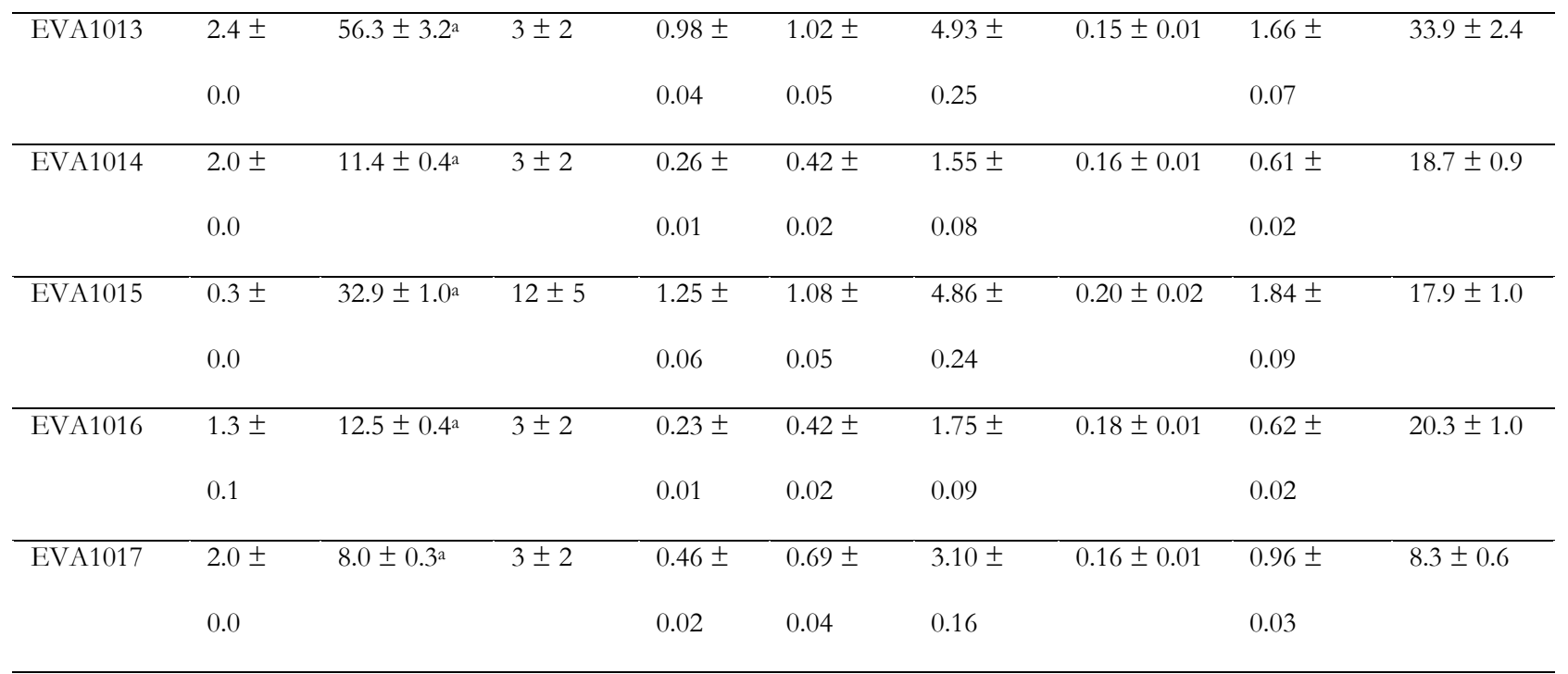

3

4 a Calculated using the central age model of Galbraith et al. (1999).

5 b Calculated using the finite mixture model of Galbraith et al. (1999).

6 c Calculated using the minimum age model of Galbraith et al. (1999).

7

8

9 


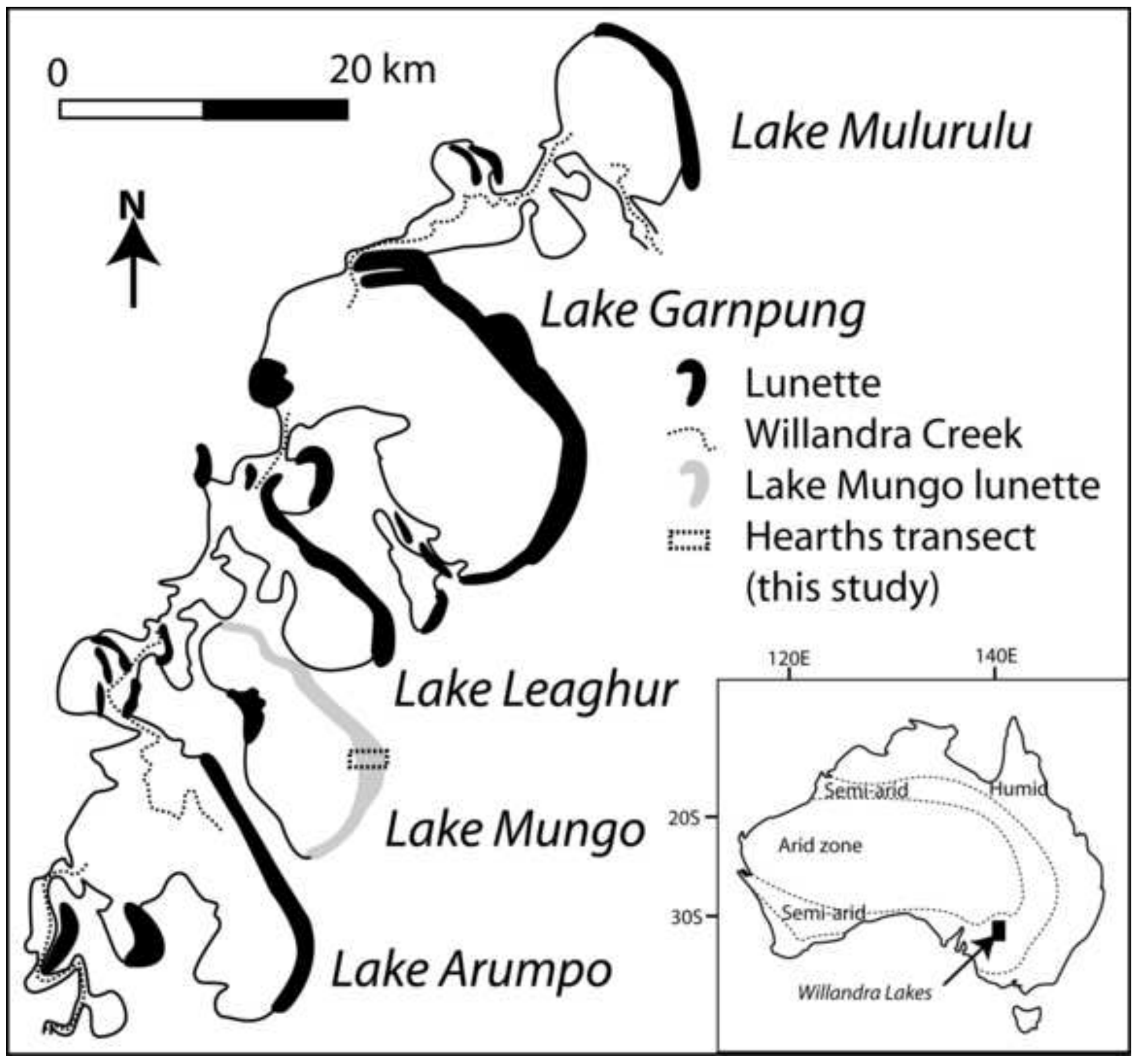


Figure 2

Click here to download high resolution image

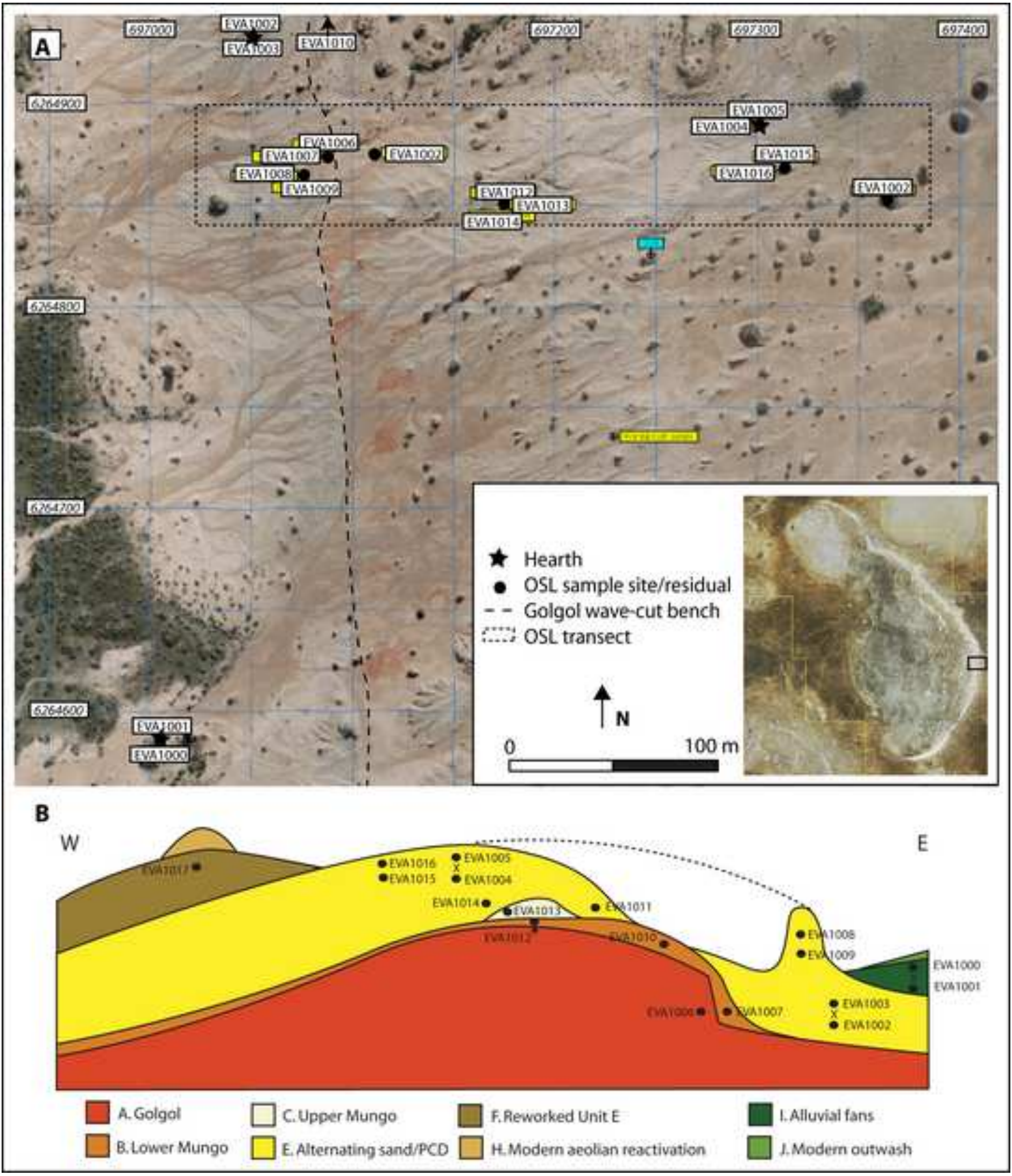




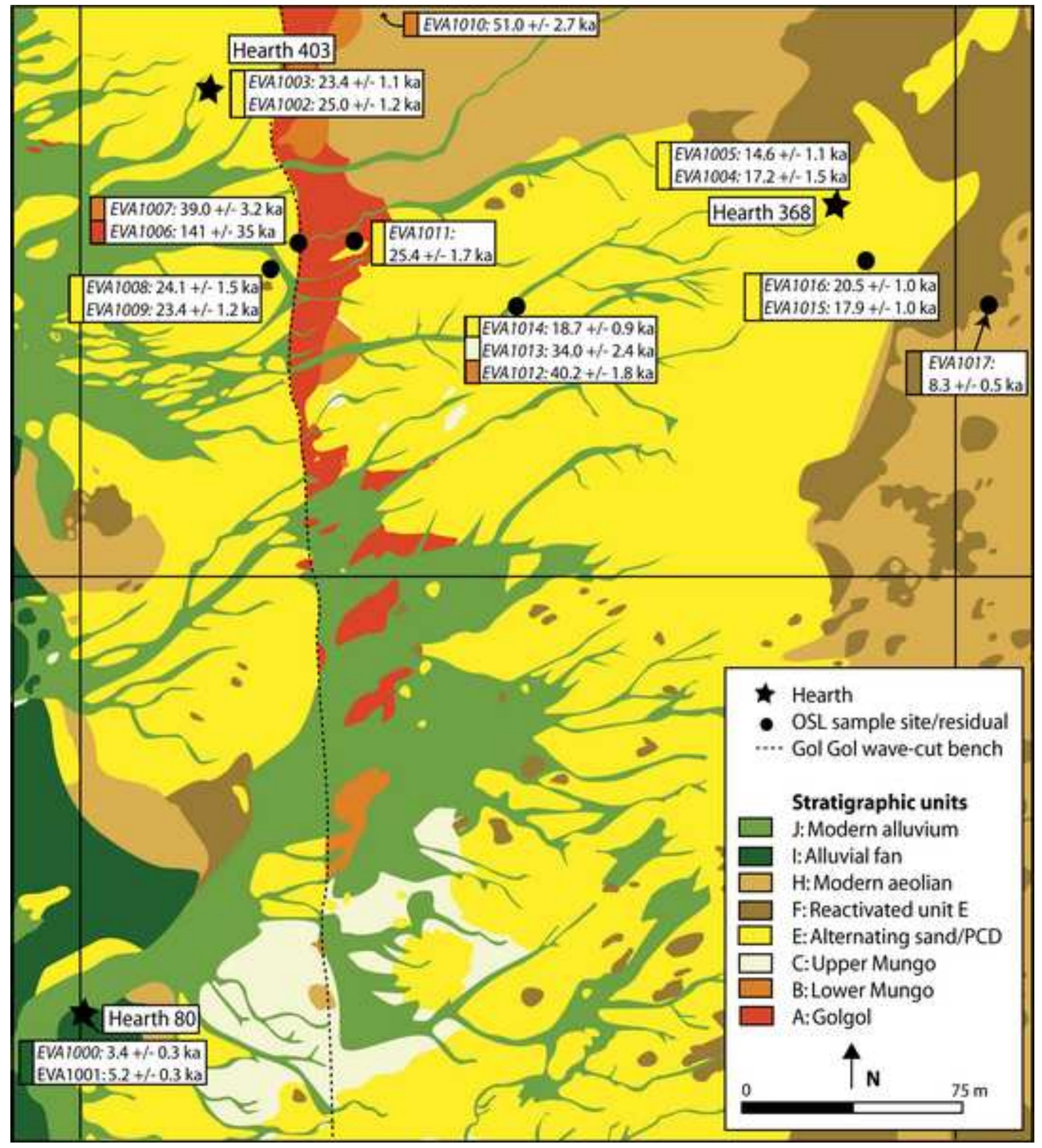


Figure 4

Click here to download high resolution image

A. EVA1002
(Unit E)
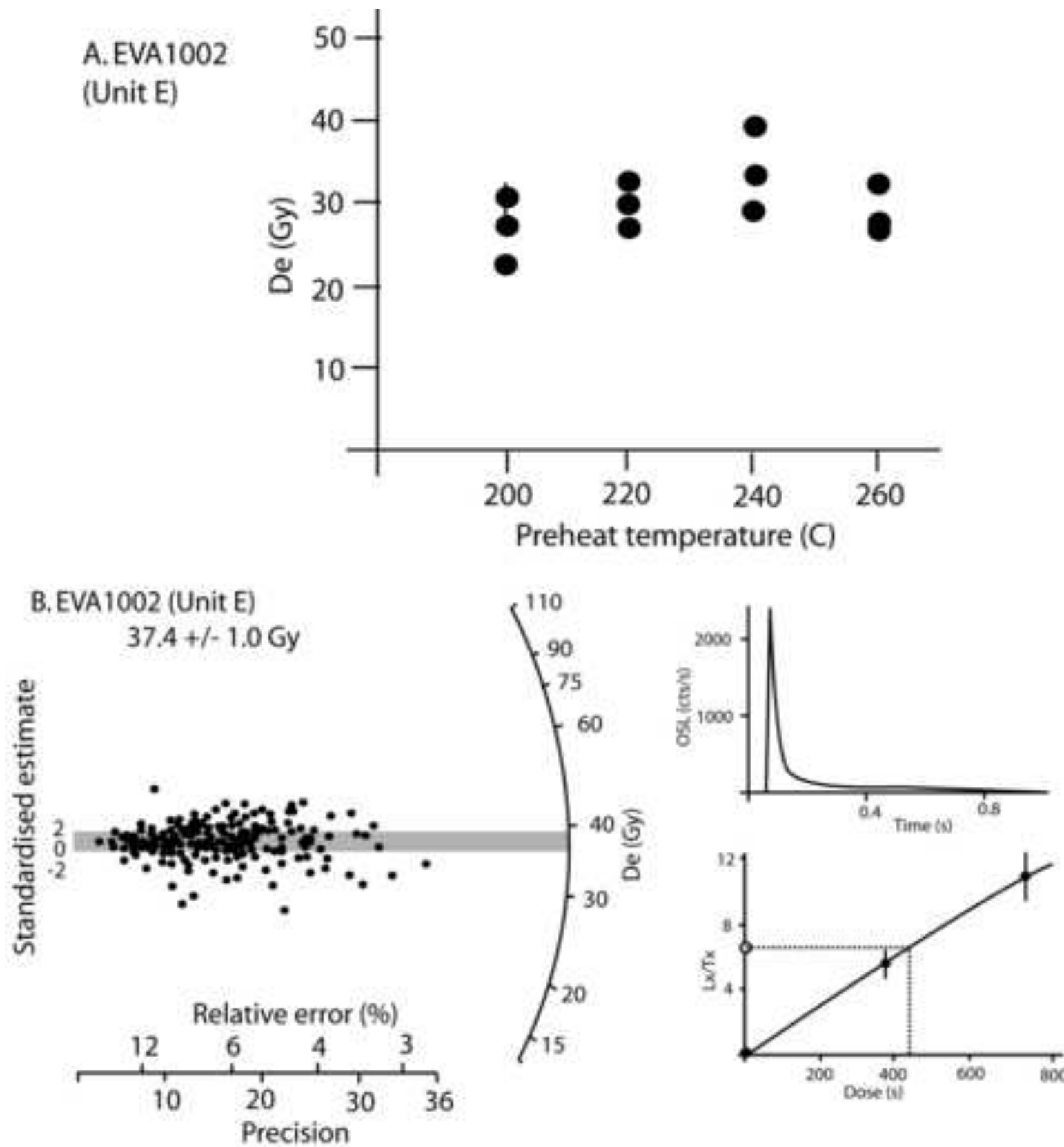

C. EVA 1000 (Unit I)
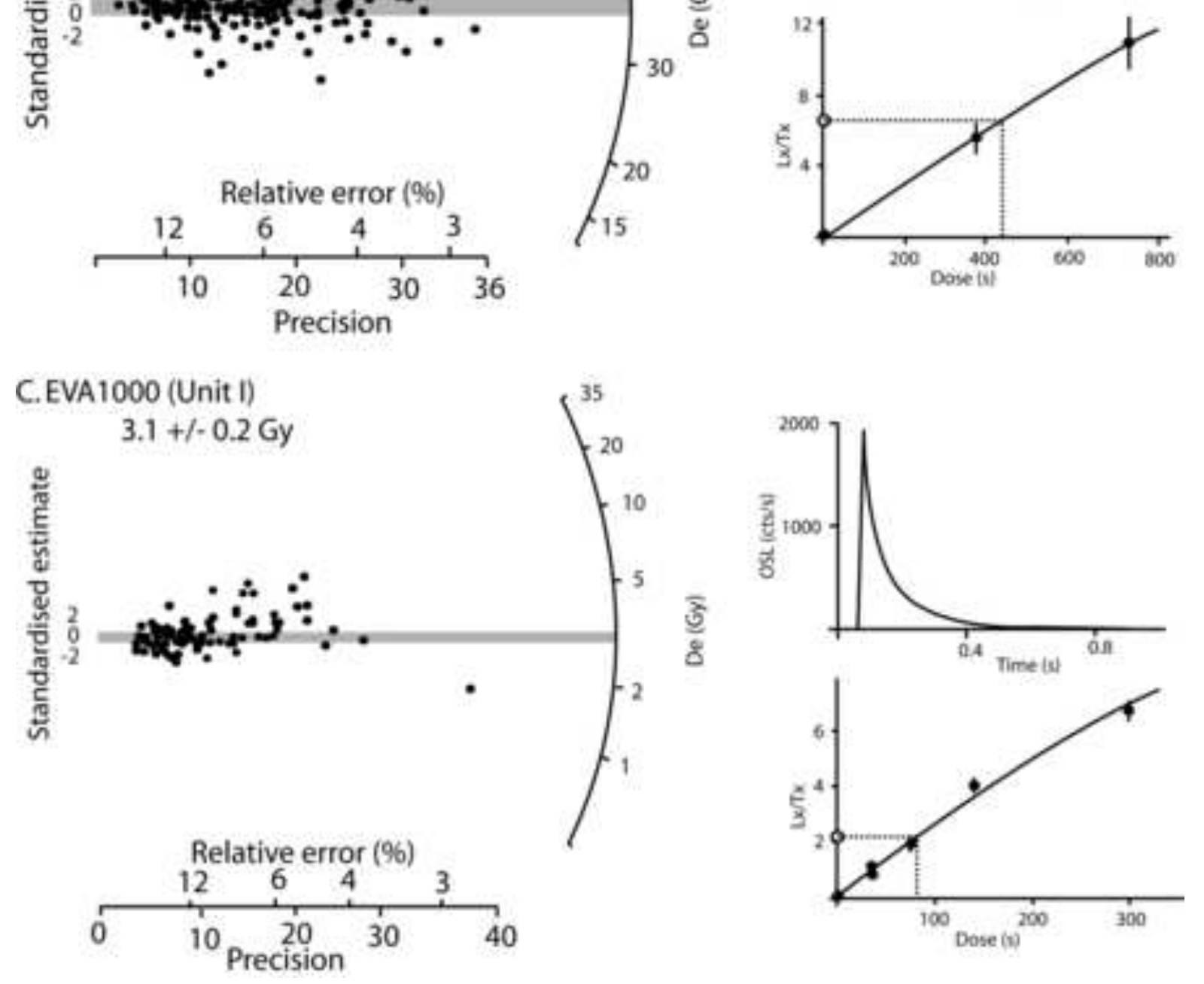


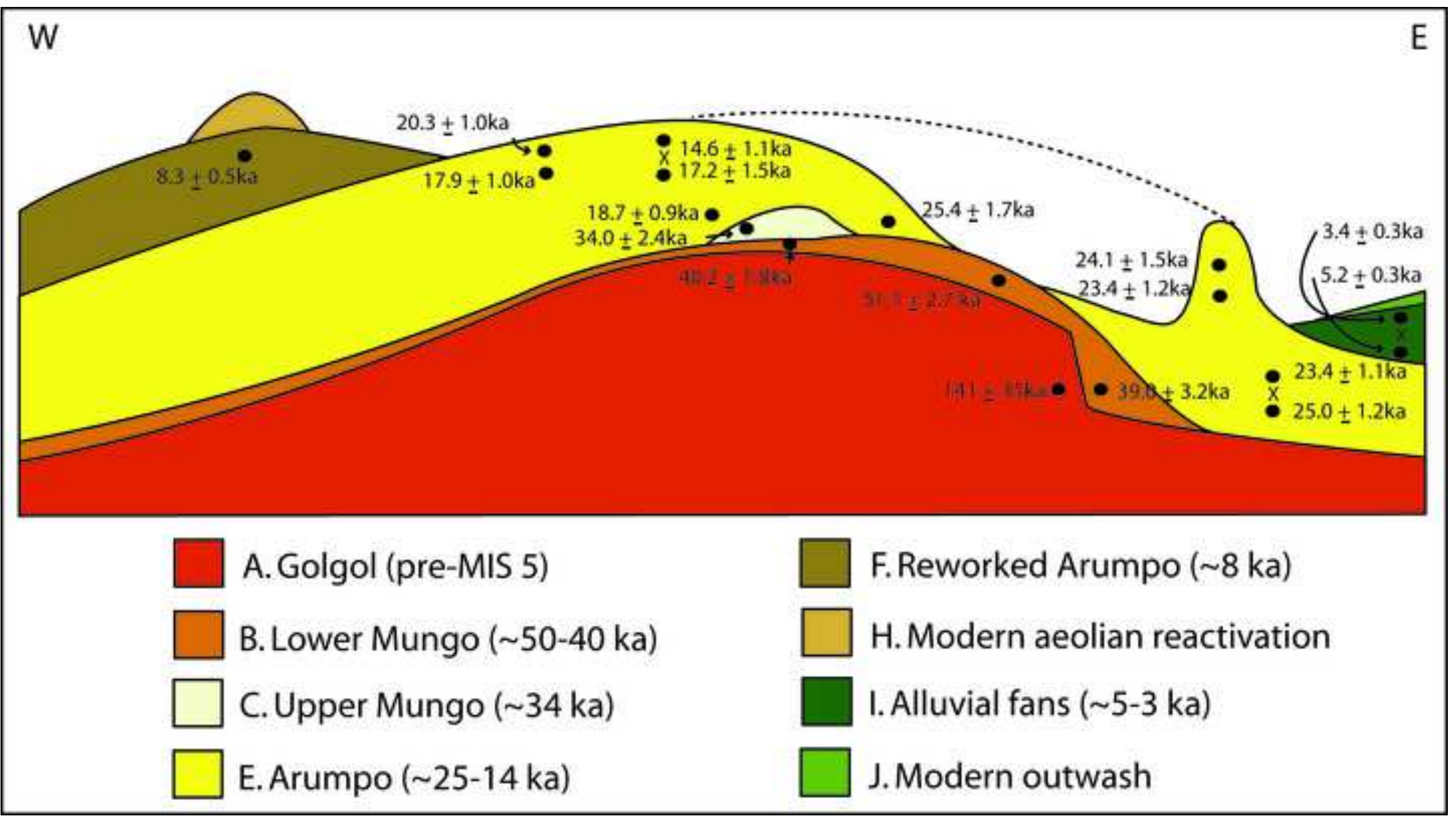


A.
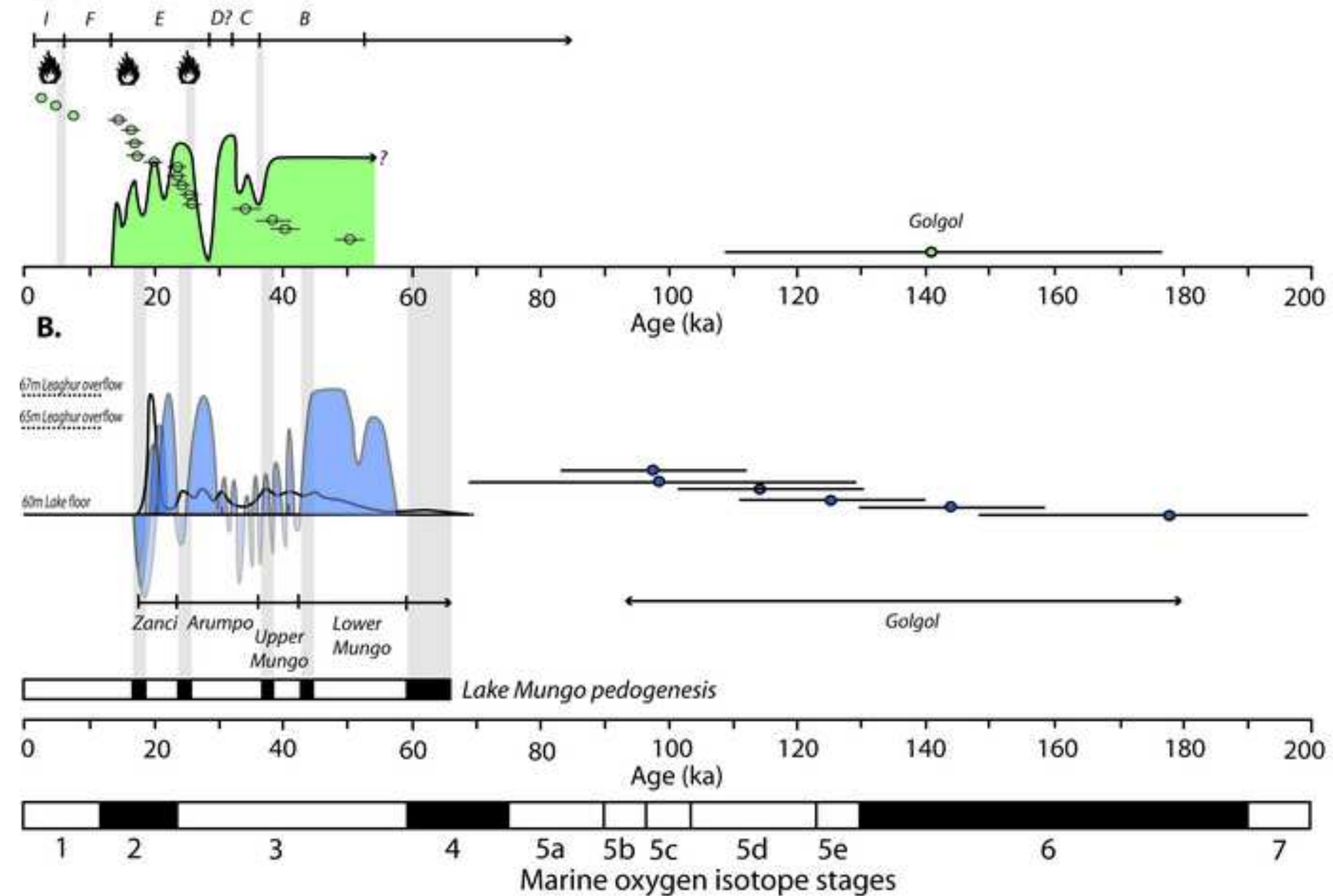

Mungo lake level and ages (this study)

- Mungo lake level and ages (Bowler et al. 2012;

- Lake Mungo hearths (this study) Bowler 1998) 
A.
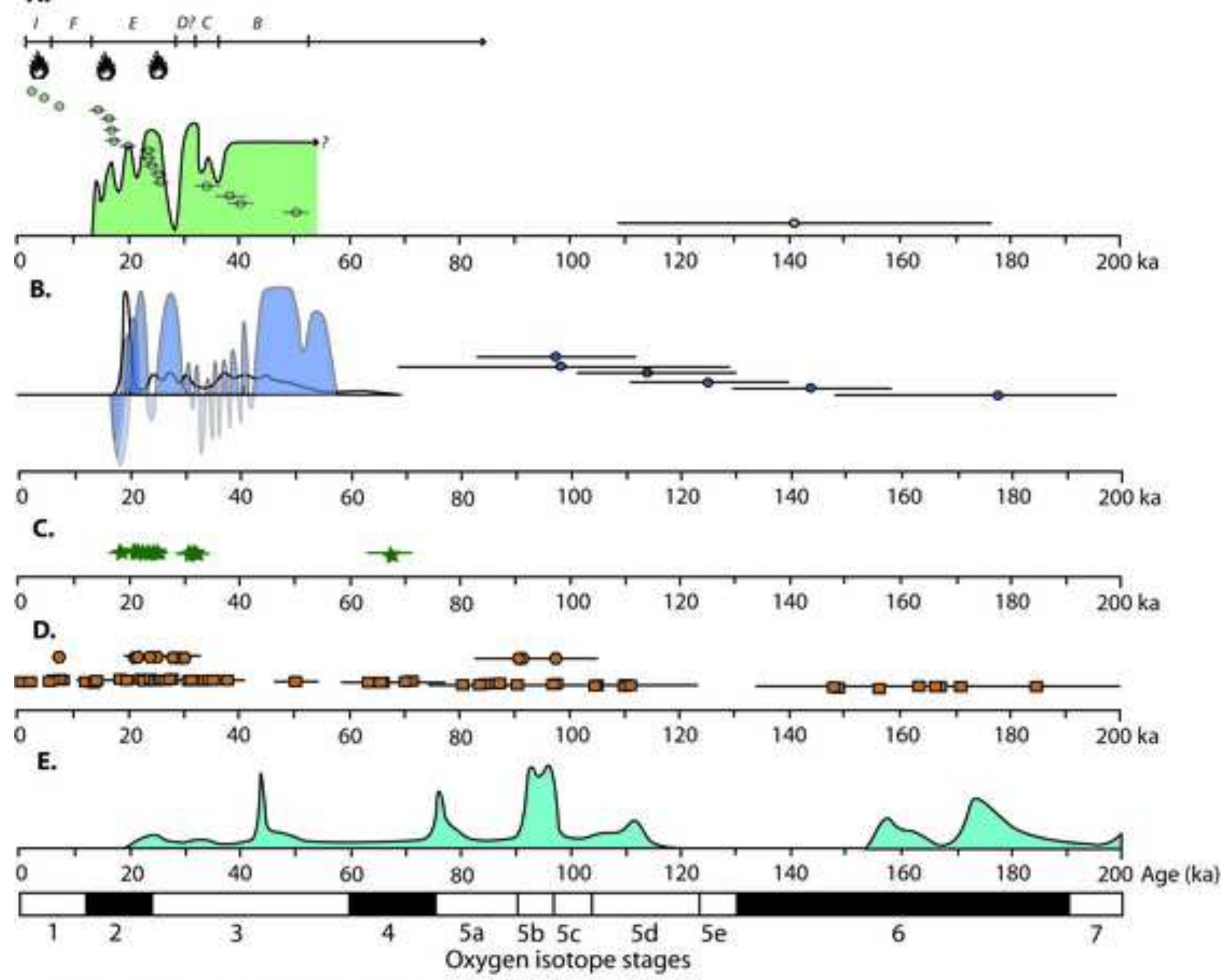

Mungo lake level and ages (this study)

b Lake Mungo hearths (this study)

- Mungo lake level and ages (Bowler et al. 2012; Bowler 1998)

* Lachlan River fluvial activity

- MDB subparabolic dune activity

๑ MDB linear dune activity

Naracoorte speleothem growth 
Click here to download high resolution image

A.

A. $67 \mathrm{~m}$ Leaghur overflow

65 m Leaghur overflow

$60 \mathrm{~m}$ lake floor
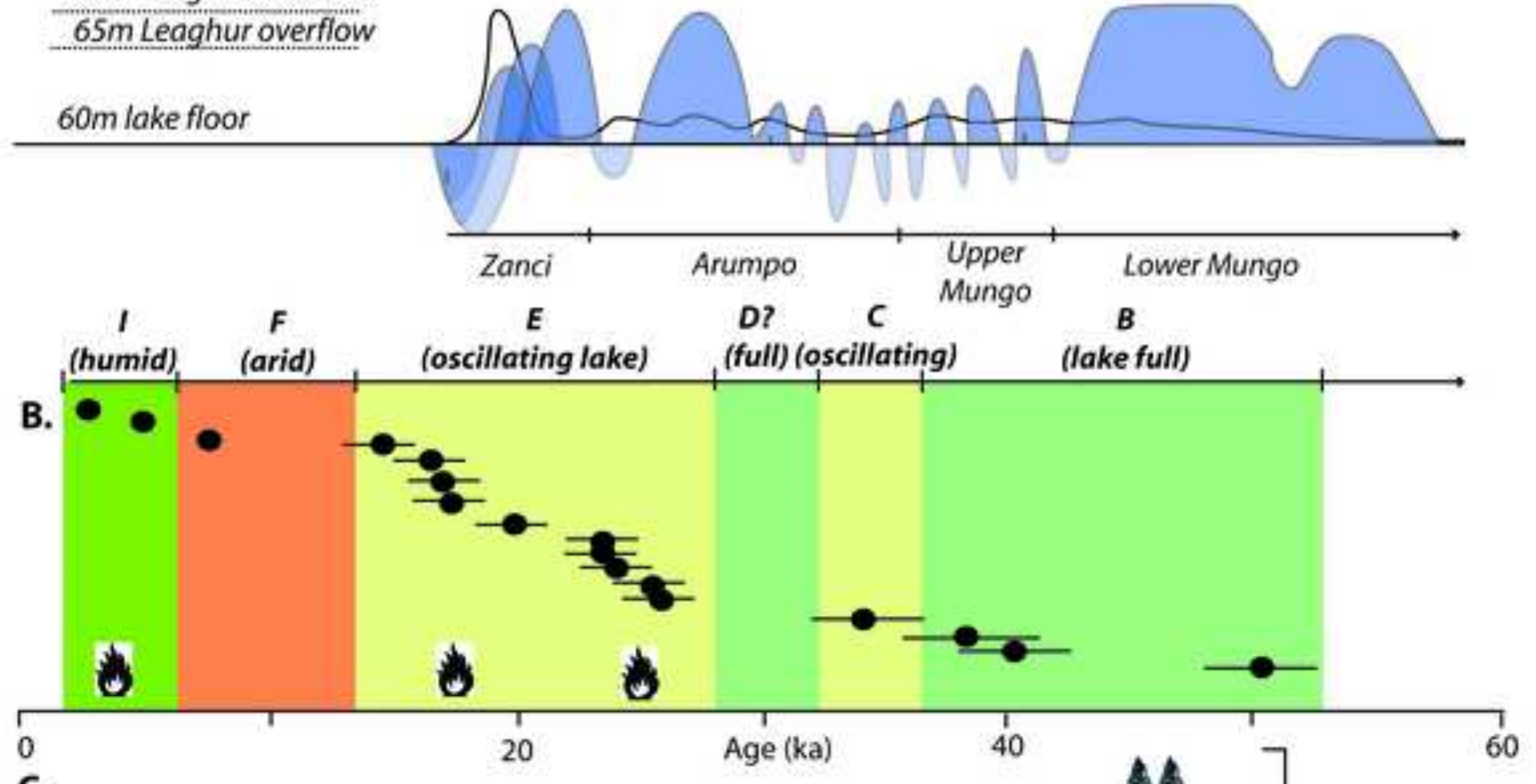

C.

()) 1

Lake Mungo

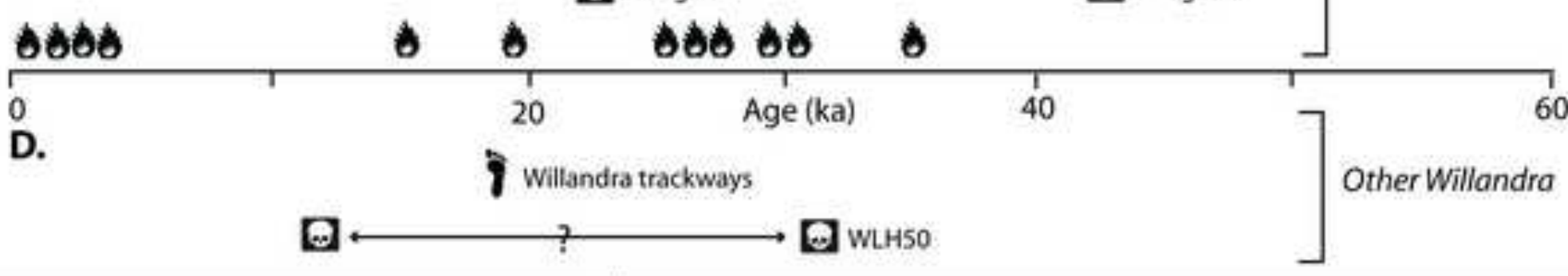

\begin{tabular}{|c|c|c|}
\hline Palaeoenvironment & Archaeo & gical traces \\
\hline $\begin{array}{l}\text { Mungo lake level (Bowler et al. 2012; } \\
\text { Bowler 1998) } \\
\text { - Lake Mungo chronology (this study) }\end{array}$ & $\begin{array}{l}\text { Oldest stone artefacts } \\
\text { Human remains } \\
\text { Willandra trackways }\end{array}$ & $\begin{array}{l}\text { Hearths } \\
\text { Bettong remains (within hearth) }\end{array}$ \\
\hline
\end{tabular}


Supplementary Material

Click here to download Supplementary Material: fitzsimmons et al_hearths_supplementary information_050713.docx

(

plementary Material: fitzsimmo

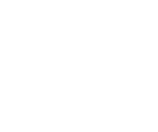

(1) $x^{2}$ (1) (1) (1) . . . . . . . . . . . . 
Inline Supplementary Figure 1

Click here to download high resolution image

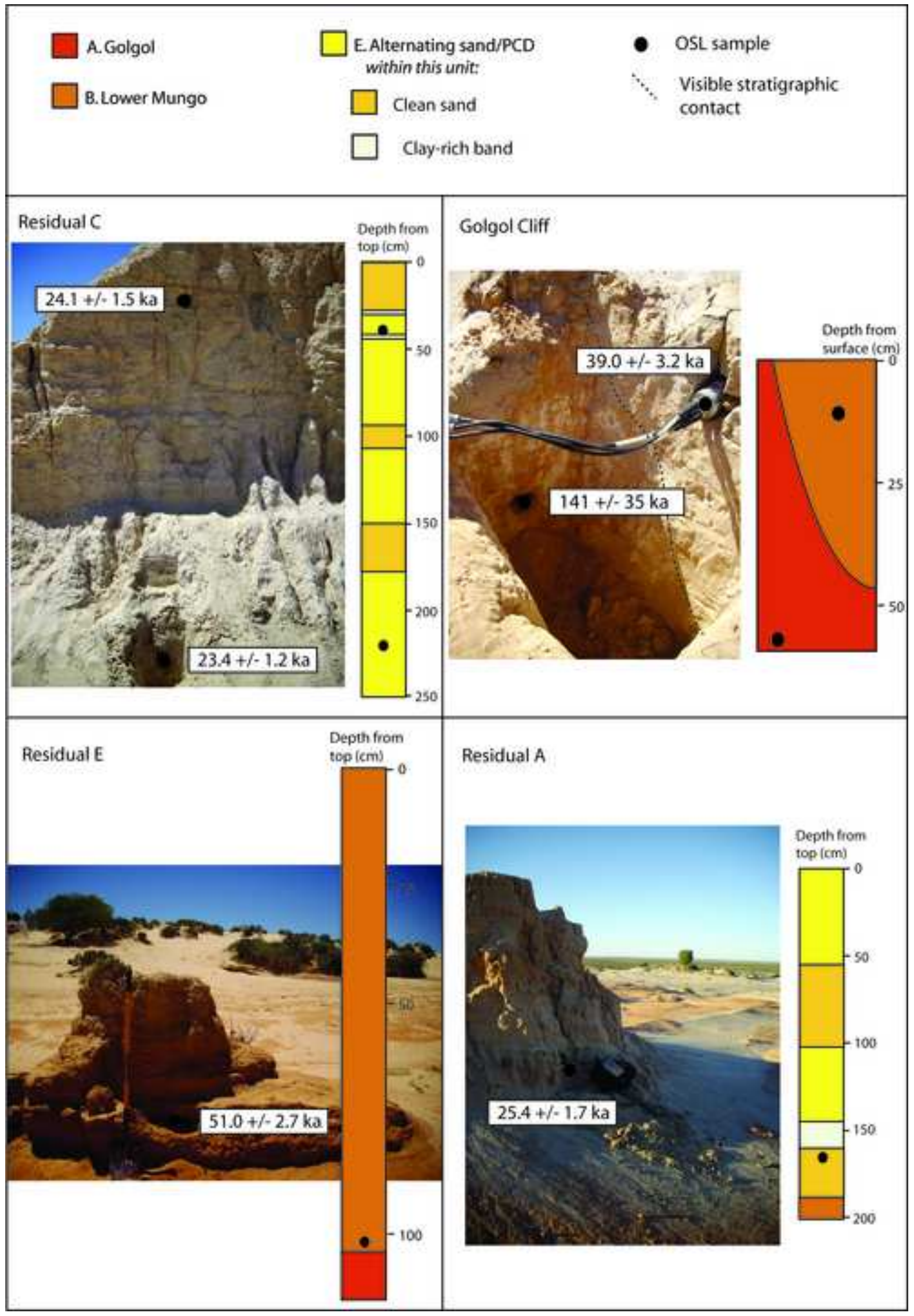


Inline Supplementary Figure 2

Click here to download high resolution image

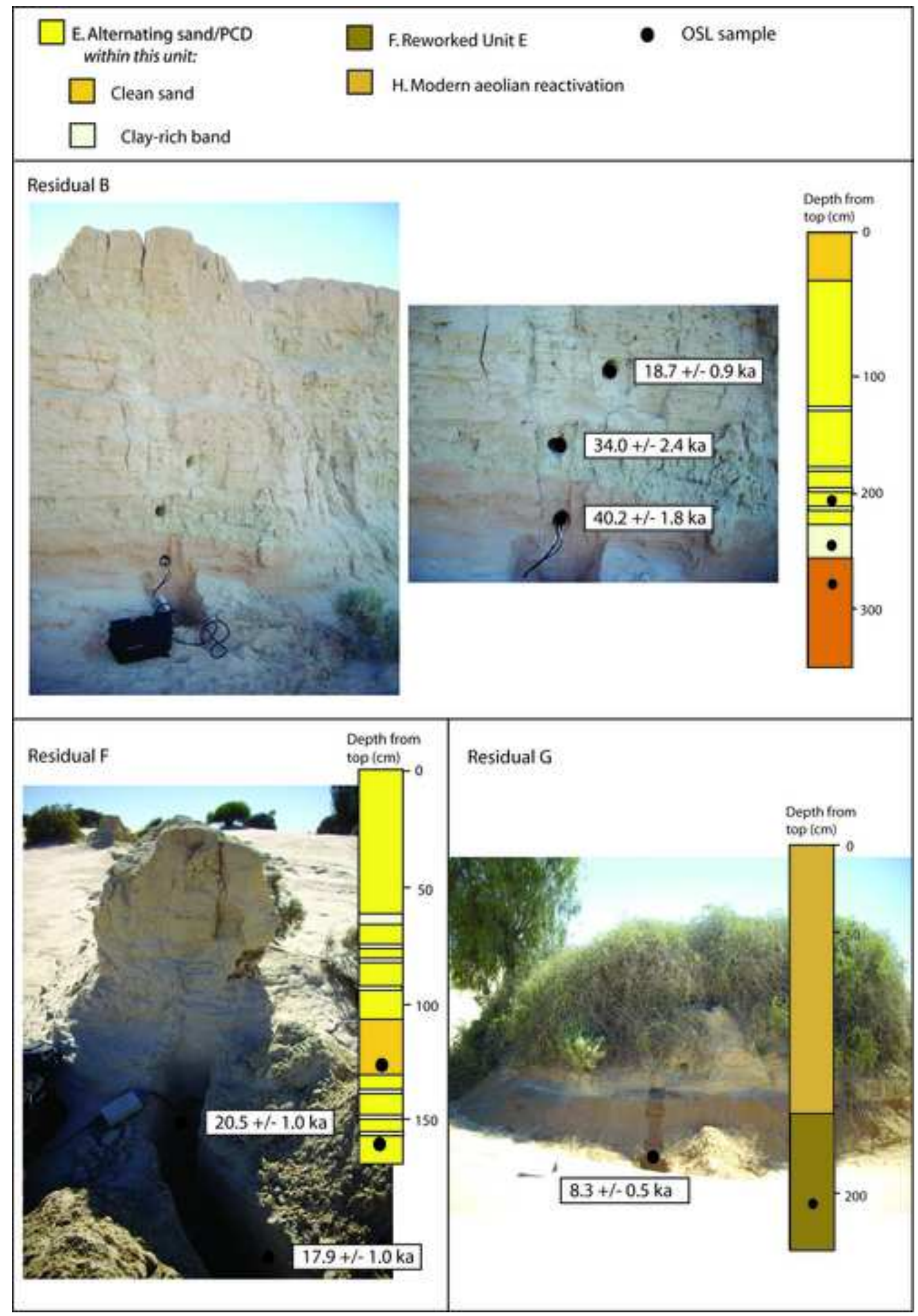


Inline Supplementary Figure 3
Click here to download high resolution image
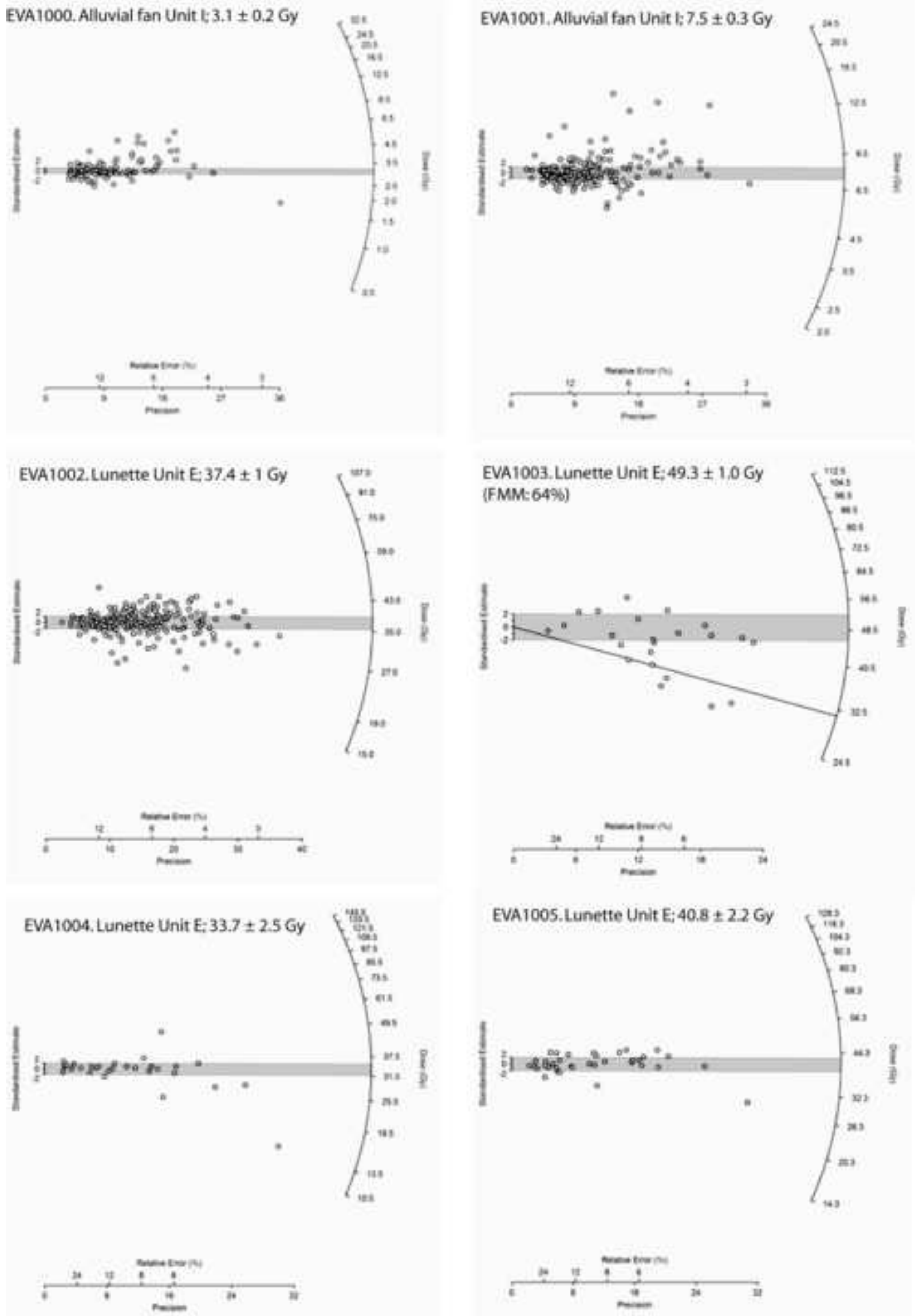


\section{Click here to download high resolution image}
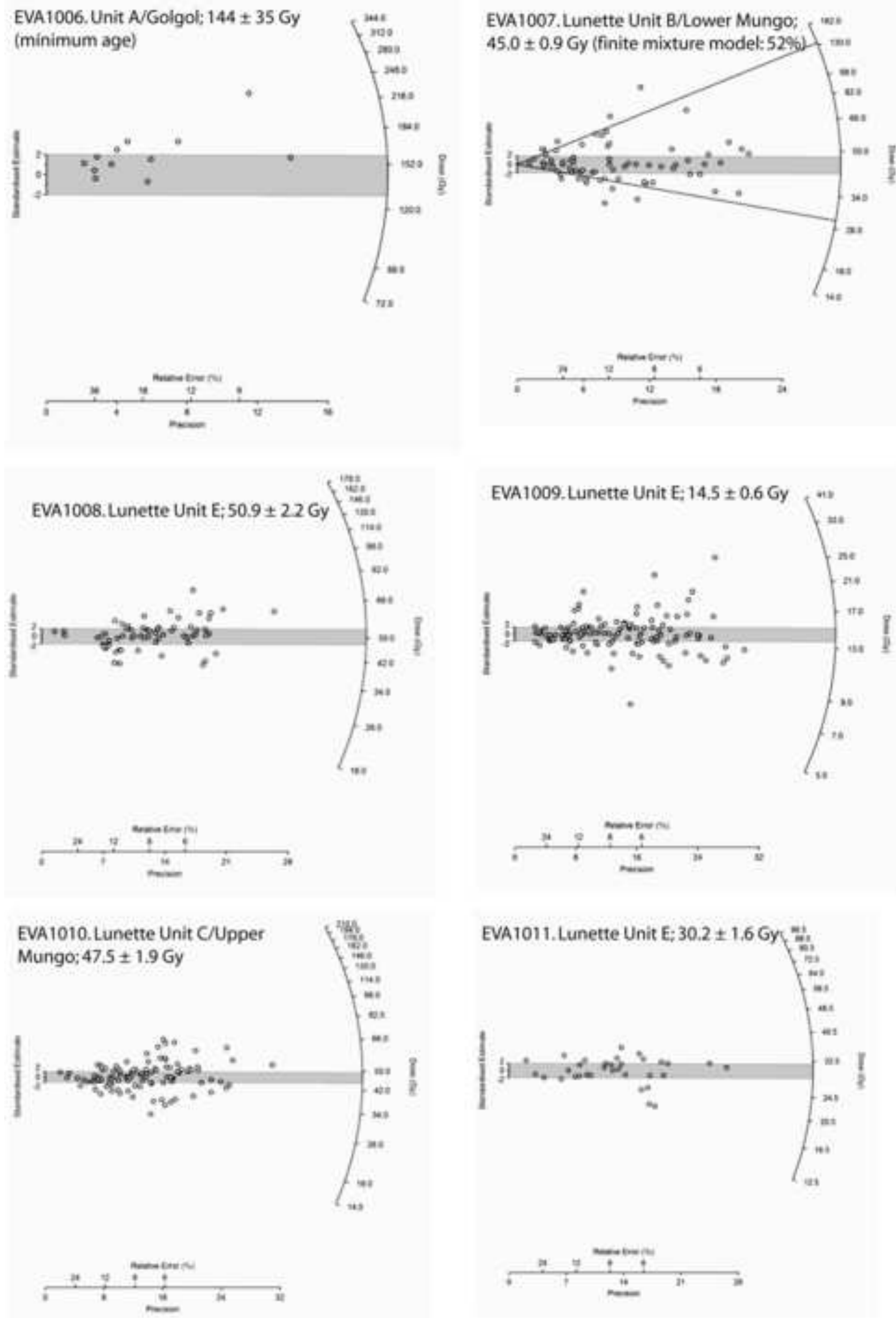


\section{Click here to download high resolution image}
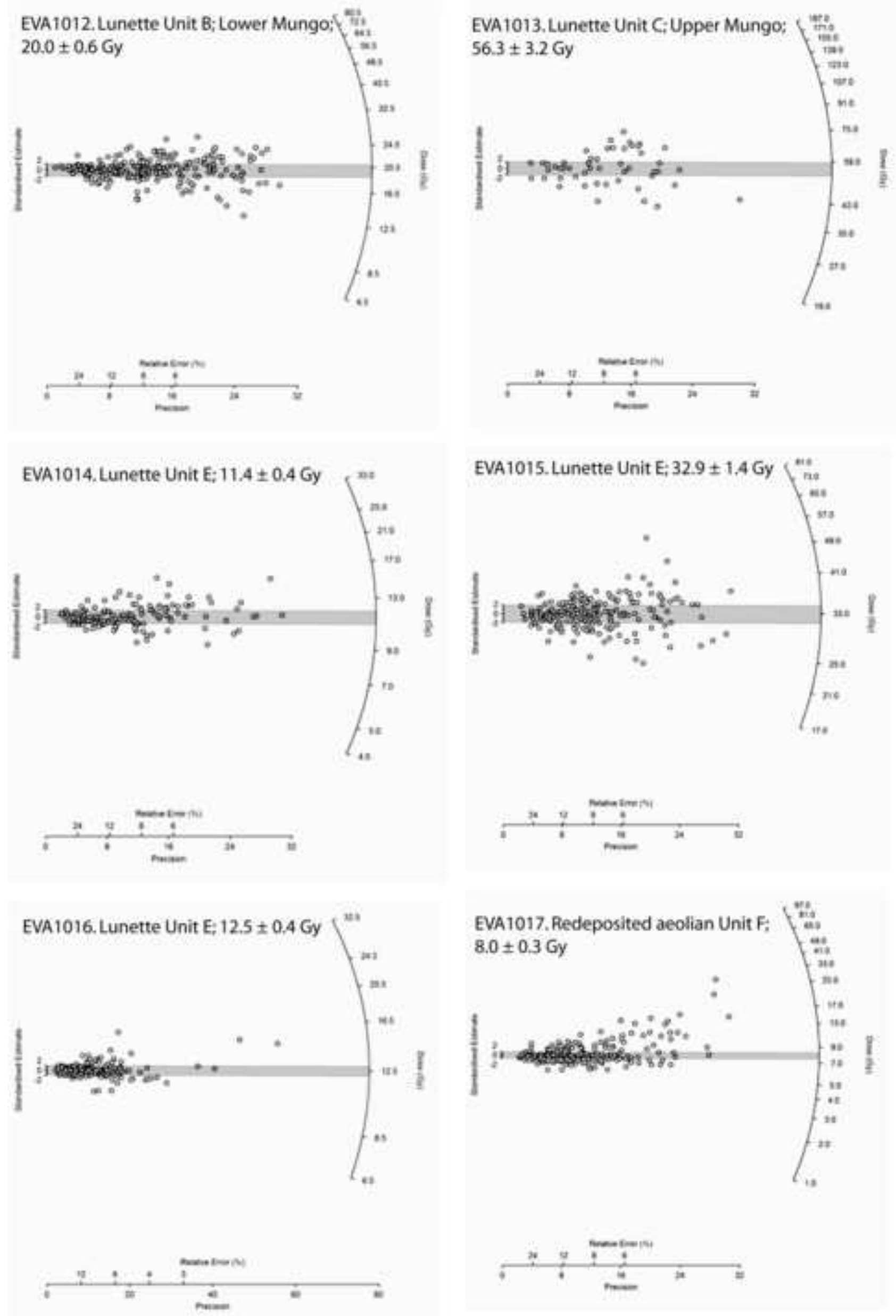
Table S1. OSL sample laboratory and field codes, and GPS locations.

\begin{tabular}{|c|c|c|c|c|}
\hline \multirow{2}{*}{$\begin{array}{c}\text { Laboratory code } \\
\text { (used in text) }\end{array}$} & \multirow[t]{2}{*}{ Field code } & \multirow[t]{2}{*}{ Residual } & \multicolumn{2}{|c|}{ GPS coordinates } \\
\hline & & & Latitude & Longitude \\
\hline EVA1000 & 80.1 & Hearth 80 & $33^{\circ} 44.428^{\prime} \mathrm{S}$ & $143^{\circ} 07.598^{\prime} \mathrm{E}$ \\
\hline EVA1001 & 80.2 & & & \\
\hline EVA1002 & 403.1 & Hearth 403 & $33^{\circ} 44.246^{\prime} \mathrm{S}$ & $143^{\circ} 07.622^{\prime} \mathrm{E}$ \\
\hline EVA1003 & 403.2 & & & \\
\hline EVA1004 & 368.1 & Hearth 368 & $33^{\circ} 44.260^{\prime} \mathrm{S}$ & $143^{\circ} 07.787^{\prime} \mathrm{E}$ \\
\hline EVA1005 & 368.2 & & & \\
\hline EVA1006 & NS1 & Golgol cliff & $33^{\circ} 44.273^{\prime} \mathrm{S}$ & $143^{\circ} 07.650^{\prime} \mathrm{E}$ \\
\hline EVA1007 & NS2 & & & \\
\hline EVA1008 & NS3 & $\mathrm{C}$ & $33^{\circ} 44.277^{\prime} \mathrm{S}$ & $143^{\circ} 07.639^{\prime} \mathrm{E}$ \\
\hline EVA1009 & NS4 & & & \\
\hline EVA1010 & NS5 & $E$ & $33^{\circ} 44.196^{\prime} \mathrm{S}$ & $143^{\circ} 07.656^{\prime} \mathrm{E}$ \\
\hline EVA1011 & NS6 & A & $33^{\circ} 44.270^{\prime} \mathrm{S}$ & $143^{\circ} 07.666^{\prime} \mathrm{E}$ \\
\hline EVA1012 & NS7 & B & $33^{\circ} 44.282^{\prime} \mathrm{S}$ & $143^{\circ} 07.704^{\prime} \mathrm{E}$ \\
\hline EVA1013 & NS8 & & & \\
\hline EVA1014 & NS9 & & & \\
\hline EVA1015 & NS10 & $\mathrm{F}$ & $33^{\circ} 44.272^{\prime} \mathrm{S}$ & $143^{\circ} 07.796^{\prime} \mathrm{E}$ \\
\hline EVA1016 & NS11 & & & \\
\hline EVA1017 & NS12 & G & $33^{\circ} 44.281^{\prime} \mathrm{S}$ & $143^{\circ} 07.827^{\prime} \mathrm{E}$ \\
\hline
\end{tabular}


Inline Supplementary Table 2

Click here to download Inline Supplementary Table: Table S2.docx

Table S2. Overdispersion values for OSL samples.

\begin{tabular}{|c|c|c|}
\hline Sample code & De (Gy) & Overdispersion (\%) \\
\hline EVA1000 & $3.1 \pm 0.2$ & 69 \\
\hline EVA1001 & $7.5 \pm 0.3$ & 46 \\
\hline EVA1002 & $37.4 \pm 1.0$ & 27 \\
\hline EVA1003 & $49.3 \pm 1.0$ & 29 \\
\hline EVA1004 & $33.7 \pm 2.5$ & 34 \\
\hline EVA1005 & $40.8 \pm 2.2$ & 25 \\
\hline EVA1006 & $144 \pm 35$ & 22 \\
\hline EVA1007 & $45.0 \pm 0.9$ & 25 \\
\hline EVA1008 & $50.9 \pm 2.2$ & 29 \\
\hline EVA1009 & $14.5 \pm 0.6$ & 36 \\
\hline EVA1010 & $47.5 \pm 1.9$ & 36 \\
\hline EVA1011 & $30.2 \pm 1.6$ & 26 \\
\hline EVA1012 & $20.0 \pm 0.6$ & 29 \\
\hline EVA1013 & $56.3 \pm 3.2$ & 39 \\
\hline EVA1014 & $11.4 \pm 0.4$ & 28 \\
\hline EVA1015 & $32.9 \pm 1.0$ & 28 \\
\hline EVA1016 & $12.5 \pm 0.4$ & 25 \\
\hline EVA1017 & $8.0 \pm 0.3$ & 54 \\
\hline
\end{tabular}


Table S3. Results from finite mixture model analyses.

\begin{tabular}{lllll}
\hline Sample code & $\begin{array}{l}\text { Number of } \\
\text { components }\end{array}$ & De (Gy) & \% population & BIC \\
\hline EVA1003 & 2 & $49.3 \pm 1.0$ & $64 \%$ & 19 \\
& & $31.5 \pm 0.2$ & $36 \%$ & $141^{1}$ \\
\hline EVA1007 & 3 & $45.0 \pm 0.9$ & $52 \%$ & \\
& & $27.9 \pm 0.1$ & $30 \%$ & \\
\hline
\end{tabular}

${ }^{1}$ This was the lowest value achieved with the model given a reasonable number of components and the small sample size. The small sample size reflects the low proportion of grains which passed the selection criteria, since most luminescent grains were saturated with respect to the dose-response curve. 
Table S4. Published ages from stratigraphic units from the Lake Mungo lunette. Note: WOCT refers to the Walls of China Tourist site.

\begin{tabular}{|c|c|c|c|c|c|}
\hline $\begin{array}{l}\text { Stratigraphic } \\
\text { Unit }\end{array}$ & Age (ka) & $\begin{array}{c}\text { Dating } \\
\text { technique }\end{array}$ & $\begin{array}{c}\text { Location on } \\
\text { lunette }\end{array}$ & Reference & Comments \\
\hline Arumpo/Zancia & $19.1 \pm 0.2$ & ${ }^{14} \mathrm{C}$ (calibrated) ${ }^{\mathrm{b}}$ & Central (WOCT) & Bowler et al. (2012) & Shell \\
\hline Arumpo/Zancia & $19.2 \pm 0.2$ & ${ }^{14} \mathrm{C}$ (calibrated) $)^{\mathrm{b}}$ & BMLM158 & Bowler et al. (2012) & Otolith \\
\hline Arumpo/Zancia & $19.2 \pm 0.2$ & ${ }^{14} \mathrm{C}$ (calibrated) ${ }^{\mathrm{b}}$ & LAC9009 & Bowler et al. (2012) & Otolith \\
\hline Arumpo/Zanci ${ }^{a}$ & $19.2 \pm 0.2$ & ${ }^{14} \mathrm{C}$ (calibrated) ${ }^{\mathrm{b}}$ & Central (WOCT) & Bowler et al. (2012) & Otolith \\
\hline Arumpo/Zancia & $19.3 \pm 0.2$ & ${ }^{14} \mathrm{C}$ (calibrated) ${ }^{\mathrm{b}}$ & Central (WOCT) & Bowler et al. (2012) & Otolith \\
\hline Arumpo/Zancia & $19.3 \pm 0.2$ & ${ }^{14} \mathrm{C}$ (calibrated) ${ }^{\mathrm{b}}$ & Central (WOCT) & Bowler et al. (2012) & Otolith \\
\hline Arumpo/Zancia & $19.3 \pm 0.3$ & ${ }^{14} \mathrm{C}$ (calibrated) ${ }^{\mathrm{b}}$ & Central (WOCT) & Bowler et al. (2012) & Otolith \\
\hline Arumpo/Zancia & $19.3 \pm 0.2$ & ${ }^{14} \mathrm{C}$ (calibrated) ${ }^{\mathrm{b}}$ & Central (WOCT) & Bowler et al. (2012) & Otolith \\
\hline Arumpo/Zanci ${ }^{a}$ & $19.4 \pm 0.2$ & ${ }^{14} \mathrm{C}$ (calibrated) ${ }^{\mathrm{b}}$ & Central (WOCT) & Bowler et al. (2012) & Otolith \\
\hline Arumpo/Zancia & $19.5 \pm 0.2$ & ${ }^{14} \mathrm{C}$ (calibrated) ${ }^{\mathrm{b}}$ & Central (WOCT) & Bowler et al. (2012) & Otolith \\
\hline Arumpo/Zanci ${ }^{a}$ & $19.6 \pm 0.2$ & ${ }^{14} \mathrm{C}$ (calibrated) ${ }^{\mathrm{b}}$ & Central (WOCT) & Bowler et al. (2012) & Otolith \\
\hline Arumpo/Zancia & $19.7 \pm 0.2$ & ${ }^{14} \mathrm{C}$ (calibrated) ${ }^{\mathrm{b}}$ & Central (WOCT) & Bowler et al. (2012) & Otolith \\
\hline Arumpo/Zancia & $19.8 \pm 0.2$ & ${ }^{14} \mathrm{C}$ (calibrated) ${ }^{\mathrm{b}}$ & Central (WOCT) & Bowler et al. (2012) & Otolith \\
\hline Arumpo/Zancia & $19.9 \pm 0.2$ & ${ }^{14} \mathrm{C}$ (calibrated) ${ }^{\mathrm{b}}$ & BMLM011 & Bowler et al. (2012) & Otolith \\
\hline Arumpo/Zancia & $20.0 \pm 0.2$ & ${ }^{14} \mathrm{C}$ (calibrated) ${ }^{\mathrm{b}}$ & Central (WOCT) & Bowler et al. (2012) & Otolith \\
\hline Arumpo/Zancia & $20.0 \pm 0.2$ & ${ }^{14} \mathrm{C}$ (calibrated) ${ }^{\mathrm{b}}$ & LAC9004 & Bowler et al. (2012) & Otolith \\
\hline Arumpo/Zancia & $20.2 \pm 0.2$ & ${ }^{14} \mathrm{C}$ (calibrated) ${ }^{\mathrm{b}}$ & BMLM008 & Bowler et al. (2012) & Otolith \\
\hline Arumpo/Zanci ${ }^{a}$ & $20.2 \pm 0.2$ & ${ }^{{ }^{14} \mathrm{C}}$ (calibrated) ${ }^{\mathrm{b}}$ & Central (WOCT) & Bowler et al. (2012) & Otolith \\
\hline Arumpo/Zancia & $20.2 \pm 0.2$ & ${ }^{14} \mathrm{C}$ (calibrated) ${ }^{\mathrm{b}}$ & BMLM010 & Bowler et al. (2012) & Otolith \\
\hline Arumpo/Zancia & $20.3 \pm 0.2$ & ${ }^{14} \mathrm{C}$ (calibrated) ${ }^{\mathrm{b}}$ & BMLM007 & Bowler et al. (2012) & Otolith \\
\hline Arumpo/Zancia & $20.3 \pm 0.2$ & ${ }^{14} \mathrm{C}$ (calibrated) ${ }^{\mathrm{b}}$ & BMLM211 & Bowler et al. (2012) & Otolith \\
\hline Arumpo/Zancia & $20.4 \pm 0.2$ & ${ }^{14} \mathrm{C}$ (calibrated) ${ }^{\mathrm{b}}$ & $\mathrm{MN}$ & Bowler et al. (2012) & Shell \\
\hline Arumpo/Zancia & $20.4 \pm 0.2$ & ${ }^{14} \mathrm{C}$ (calibrated) ${ }^{\mathrm{b}}$ & LAC9001 & Bowler et al. (2012) & Otolith \\
\hline Arumpo/Zancia & $20.5 \pm 0.2$ & ${ }^{14} \mathrm{C}$ (calibrated) ${ }^{\mathrm{b}}$ & BMLM121 & Bowler et al. (2012) & Otolith \\
\hline Arumpo/Zancia & $20.8 \pm 0.2$ & ${ }^{14} \mathrm{C}$ (calibrated) ${ }^{\mathrm{b}}$ & LAC9008 & Bowler et al. (2012) & Otolith \\
\hline Arumpo/Zancia & $24.6 \pm 0.2$ & ${ }^{14} \mathrm{C}$ (calibrated) ${ }^{\mathrm{b}}$ & LMB1-01 & Bowler et al. (2012) & Otolith \\
\hline Arumpo/Zancia & $25.1 \pm 0.2$ & ${ }^{14} \mathrm{C}$ (calibrated) ${ }^{\mathrm{b}}$ & BMLM156 & Bowler et al. (2012) & Otolith \\
\hline Arumpo & $24.6 \pm 2.4$ & TL & $\begin{array}{l}\text { South (Mungo } \\
\text { III) }\end{array}$ & Oyston (1996) & \\
\hline Arumpo & $29.3 \pm 3.1$ & $\mathrm{TL}$ & $\begin{array}{l}\text { South (Mungo } \\
\text { III) }\end{array}$ & $\begin{array}{l}\text { Bowler and Price } \\
\text { (1998) }\end{array}$ & \\
\hline Arumpo & $25.0 \pm 0.7$ & ${ }^{14} \mathrm{C}$ (calibrated) & $\begin{array}{l}\text { South (Mungo } \\
\text { III) }\end{array}$ & Bowler (1998) & \\
\hline Arumpo & $24.9 \pm 1.0$ & ${ }^{14} \mathrm{C}$ (calibrated) & $\begin{array}{l}\text { South (Mungo } \\
\text { III) }\end{array}$ & Bowler (1998) & \\
\hline Arumpo & $30.3 \pm 1.0$ & $\overline{\text { OSL }}$ & $\begin{array}{l}\text { South (Mungo } \\
\text { III) }\end{array}$ & Bowler et al. (2003) & \\
\hline Arumpo & 24.5 & $\mathrm{TL}$ & $\begin{array}{l}\text { Central } \\
\text { (Palaeomagnetic } \\
\text { site) }\end{array}$ & Readhead (1990) & \\
\hline Arumpo & 23.3 & $\mathrm{TL}$ & $\begin{array}{l}\text { Central } \\
\text { (Palaeomag. site) }\end{array}$ & Readhead (1990) & \\
\hline Zanci & 16 & $\mathrm{TL}$ & $\begin{array}{l}\text { Central } \\
\text { (Palaeomag. site) }\end{array}$ & Readhead (1990) & \\
\hline Arumpo & $27.5 \pm 0.3$ & ${ }^{14} \mathrm{C}$ (calibrated) & Central & Bowler (1998) & \\
\hline
\end{tabular}




\begin{tabular}{|c|c|c|c|c|c|}
\hline & & & (Palaeomag. site) & & \\
\hline Arumpo & $28.3 \pm 0.4$ & ${ }^{14} \mathrm{C}$ (calibrated) & $\begin{array}{l}\text { Central } \\
\text { (Palaeomag. site) }\end{array}$ & Bowler (1998) & \\
\hline Arumpo & $30.8 \pm 0.5$ & ${ }^{14} \mathrm{C}$ (calibrated) & $\begin{array}{l}\text { Central } \\
\text { (Palaeomag. site) }\end{array}$ & Bowler (1998) & \\
\hline Arumpo & $26.3 \pm 0.3$ & ${ }^{14} \mathrm{C}$ (calibrated) & $\begin{array}{l}\text { Central } \\
\text { (Palaeomag. site) }\end{array}$ & Bowler (1998) & \\
\hline Arumpo & $31.6 \pm 4.0$ & TL & $\begin{array}{l}\text { South (Mungo } \\
\text { III) }\end{array}$ & Oyston (1996) & \\
\hline Arumpo & $22.3 \pm 2.5$ & $\mathrm{TL}$ & $\begin{array}{l}\text { Central } \\
\text { (Palaeomag. site) }\end{array}$ & Readhead (1988) & \\
\hline Upper Mungo & $42.0 \pm 1.7$ & OSL & South (Mungo I) & Bowler et al. (2003) & \\
\hline Upper Mungo & $38.2 \pm 1.3$ & OSL & $\begin{array}{l}\text { South (Mungo } \\
\text { III) }\end{array}$ & Bowler et al. (2003) & \\
\hline Upper Mungo & $37.8 \pm 1.9$ & OSL & $\begin{array}{l}\text { South (Mungo } \\
\text { III) }\end{array}$ & Bowler et al. (2003) & \\
\hline Upper Mungo & $30.6 \pm 1.1$ & OSL & $\begin{array}{l}\text { South (Mungo } \\
\text { III) }\end{array}$ & Bowler et al. (2003) & \\
\hline Upper Mungo & $34.0 \pm 3.9$ & TL & $\begin{array}{l}\text { South (Mungo } \\
\text { III) }\end{array}$ & Oyston (1996) & \\
\hline Upper Mungo & $24.5 \pm 3.7$ & TL & $\begin{array}{l}\text { Central } \\
\text { (Palaeomag. site) }\end{array}$ & Readhead (1988) & \\
\hline Upper Mungo & $29.3 \pm 3.2$ & $\mathrm{TL}$ & $\begin{array}{l}\text { Central } \\
\text { (Palaeomag. site) }\end{array}$ & Readhead (1988) & \\
\hline $\begin{array}{l}\text { Lower-Upper } \\
\text { Mungo transition }\end{array}$ & $37.1 \pm 1.1$ & ${ }^{14} \mathrm{C}$ (calibrated) ${ }^{\mathrm{b}}$ & Central (WOCT) & Bowler et al. (2012) & Shell \\
\hline $\begin{array}{l}\text { Lower-Upper } \\
\text { Mungo transition }\end{array}$ & $37.5 \pm 1.4$ & ${ }^{14} \mathrm{C}$ (calibrated) ${ }^{\mathrm{b}}$ & Central (WOCT) & Bowler et al. (2012) & Shell \\
\hline $\begin{array}{l}\text { Lower-Upper } \\
\text { Mungo transition }\end{array}$ & $37.8 \pm 0.5$ & ${ }^{14} \mathrm{C}$ (calibrated) ${ }^{\mathrm{b}}$ & LMB3-B1 & Bowler et al. (2012) & Otolith \\
\hline $\begin{array}{l}\text { Lower-Upper } \\
\text { Mungo transition }\end{array}$ & $37.9 \pm 1.1$ & ${ }^{14} \mathrm{C}$ (calibrated) ${ }^{\mathrm{b}}$ & Central (WOCT) & Bowler et al. (2012) & Otolith \\
\hline $\begin{array}{l}\text { Lower-Upper } \\
\text { Mungo transition }\end{array}$ & $38.5 \pm 1.4$ & ${ }^{14} \mathrm{C}$ (calibrated) ${ }^{\mathrm{b}}$ & Central (WOCT) & Bowler et al. (2012) & Shell \\
\hline $\begin{array}{l}\text { Lower-Upper } \\
\text { Mungo transition }\end{array}$ & $40.9 \pm 0.8$ & ${ }^{14} \mathrm{C}$ (calibrated) ${ }^{\mathrm{b}}$ & $\begin{array}{l}\text { Mungo B } \\
\text { Shawcross Pit }\end{array}$ & Bowler et al. (2012) & Otolith \\
\hline $\begin{array}{l}\text { Lower-Upper } \\
\text { Mungo transition }\end{array}$ & $41.0 \pm 0.9$ & ${ }^{14} \mathrm{C}$ (calibrated) ${ }^{\mathrm{b}}$ & Central (WOCT) & Bowler et al. (2012) & Otolith \\
\hline $\begin{array}{l}\text { Lower-Upper } \\
\text { Mungo transition }\end{array}$ & $45.2 \pm 0.5$ & ${ }^{14} \mathrm{C}$ (calibrated) ${ }^{\mathrm{b}}$ & LAC9002 & Bowler et al. (2012) & Otolith \\
\hline Lower Mungo & $52.4 \pm 3.1$ & OSL & South (Mungo I) & Bowler et al. (2003) & \\
\hline Lower Mungo & $45.7 \pm 2.3$ & OSL & South (Mungo I) & Bowler et al. (2003) & \\
\hline Lower Mungo & $47.9 \pm 2.4$ & OSL & South (Mungo I) & Bowler et al. (2003) & \\
\hline Lower Mungo & $49.1 \pm 2.7$ & OSL & South (Mungo I) & Bowler et al. (2003) & \\
\hline Lower Mungo & $50.1 \pm 2.4$ & OSL & South (Mungo I) & Bowler et al. (2003) & \\
\hline Lower Mungo & $46.1 \pm 2.3$ & OSL & South (Mungo I) & Bowler et al. (2003) & \\
\hline Lower Mungo & $42.5 \pm 2.4$ & OSL & South (Mungo I) & Bowler et al. (2003) & \\
\hline Lower Mungo & $42.7 \pm 2.5$ & OSL & South (Mungo I) & Bowler et al. (2003) & \\
\hline Lower Mungo & $44.8 \pm 3.1$ & OSL & South (Mungo I) & Bowler et al. (2003) & \\
\hline Lower Mungo & $44.9 \pm 2.4$ & OSL & South (Mungo I) & Bowler et al. (2003) & \\
\hline Lower Mungo & $45.4 \pm 2.5^{c}$ & OSL & South (Mungo I) & Bowler et al. (2003) & \\
\hline
\end{tabular}




\begin{tabular}{|c|c|c|c|c|}
\hline Lower Mungo & $62.2 \pm 1.8$ & OSL & $\begin{array}{l}\text { South (Mungo } \\
\text { III) }\end{array}$ & Bowler et al. (2003) \\
\hline Lower Mungo & $42.8 \pm 3.1$ & OSL & $\begin{array}{l}\text { South (Mungo } \\
\text { III) }\end{array}$ & Bowler et al. (2003) \\
\hline Lower Mungo & $49.2 \pm 2.1$ & OSL & $\begin{array}{l}\text { South (Mungo } \\
\text { III) }\end{array}$ & Bowler et al. (2003) \\
\hline Lower Mungo & $42.1 \pm 1.7$ & OSL & $\begin{array}{l}\text { South (Mungo } \\
\text { III) }\end{array}$ & Bowler et al. (2003) \\
\hline Lower Mungo & $49.3 \pm 3.1$ & OSL & $\begin{array}{l}\text { South (Mungo } \\
\text { III) }\end{array}$ & Bowler et al. (2003) \\
\hline Lower Mungo & $48.1 \pm 3.2$ & OSL & $\begin{array}{l}\text { South (Mungo } \\
\text { III) }\end{array}$ & Bowler et al. (2003) \\
\hline Lower Mungo & $41.9 \pm 2.4 \mathrm{c}$ & OSL & $\begin{array}{l}\text { South (Mungo } \\
\text { III) }\end{array}$ & Bowler et al. (2003) \\
\hline Lower Mungo & $42.2 \pm 2.5^{c}$ & OSL & $\begin{array}{l}\text { South (Mungo } \\
\text { III) }\end{array}$ & Bowler et al. (2003) \\
\hline Lower Mungo & $43.3 \pm 3.8$ & TL & $\begin{array}{l}\text { South (Mungo } \\
\text { III) }\end{array}$ & Oyston (1996) \\
\hline Lower Mungo & $41.4 \pm 6.7$ & TL & $\begin{array}{l}\text { South (Mungo } \\
\text { III) }\end{array}$ & $\begin{array}{l}\text { Bowler and Price } \\
\text { (1998) }\end{array}$ \\
\hline Lower Mungo & $31.4 \pm 2.1$ & $\mathrm{TL}$ & South & Bell (1991) \\
\hline Lower Mungo & $36.4 \pm 2.5$ & TL & South & Bell (1991) \\
\hline Gol Gol & $113 \pm 13$ & TL & $\begin{array}{l}\text { Central } \\
\text { (Palaeomag. site) }\end{array}$ & Bowler (1998) \\
\hline Gol Gol & $126 \pm 16$ & TL & $\begin{array}{l}\text { Central } \\
\text { (Palaeomag. site) }\end{array}$ & Bowler (1998) \\
\hline Gol Gol & $98.6 \pm 17.0$ & TL & $\begin{array}{l}\text { Central } \\
\text { (Palaeomag. site) }\end{array}$ & Bowler (1998) \\
\hline Gol Gol & $98.1 \pm 30.0$ & TL & $\begin{array}{l}\text { Central } \\
\text { (Palaeomag. site) }\end{array}$ & Bowler (1998) \\
\hline Gol Gol & $144 \pm 15$ & TL & $\begin{array}{l}\text { South (Mungo } \\
\text { III) }\end{array}$ & Oyston (1996) \\
\hline Gol Gol & $178 \pm 29$ & TL & $\begin{array}{l}\text { South (Mungo } \\
\text { III) }\end{array}$ & Oyston (1996) \\
\hline
\end{tabular}

a Stratigraphic position determined by age; not in situ.

b Calibrated using Reimer et al. (2009).

c Sample collected from paleosol. 